\title{
Time Relations and Structural-Stratigraphic Patterns in Ophiolite Accretion, West Central Klamath Mountains, California
}

\author{
Jason B. Saleeby, ${ }^{1}$ Gregory D. Harper, ${ }^{2}$ Arthur W. Snoke, ${ }^{3}$ and Warren D. Sharp ${ }^{4}$
}

\begin{abstract}
New geochronological data and published structural and stratigraphic data show that two distinctly different ophiolitic assemblages formed in general proximity to one another at nearly the same time and were subsequently imbricated along a regional thrust zone. The Josephine ophiolite constitutes a complete oceanic crust and upper mantle sequence which lies within the western Jurassic belt of the Klamath province. Within the study area the Josephine ophiolite was formed by seafloor spreading at about $157 \mathrm{~m} . \mathrm{y}$. before present. It was immediately covered by a thin pelagic and hemipelagic sequence which grades into a thick flysch sequence, both of which comprise the Galice Formation. The Galice flysch was derived from volcanic arc and uplifted continental margin orogenic assemblages. A major nonvolcanic source for the Galice flysch appears to have been the western Paleozoic and Triassic belt of the Klamath province exposed to the east. Proximal volcanic arc activity migrated to the site of the Josephine-Galice section by $151 \mathrm{~m} . \mathrm{y}$. and is represented by numerous dikes and sills which intrude the ophiolite and Galice Formation. The Preston Peak ophiolite is a polygenetic assemblage consisting of (1) a pre-mid-Jurassic tectonitic peridotite-amphibolite substrate which represents disrupted and unroofed basement of the western Paleozoic and Triassic belt and (2) an upper mafic complex which was intruded through and constructed above the tectonite substrate at about $160 \mathrm{~m}$.y. The mafic complex consists primarily of diabase hypabyssal rocks that are overlain by diabase-clast breccia and hemipelagic deposits. A major arc-plutonic complex was emplaced into the Preston Peak ophiolite in at least two pulses at 153 and $149 \mathrm{~m} . y$. Major phases of this complex consist of wehrlite, gabbro, pyroxene diorite, and homblende diorite. The Josephine ophiolite is interpreted as the remnants of interarc basin crust. The Preston Peak ophiolite is interpreted as either a primitive remnant arc complex or a rift edge facies for the Josephine interarc basin. The Galice Formation represents a submarine fan complex that was built on juvenile crust of the Josephine basin floor. During the time interval of 153 to $149 \mathrm{~m} . \mathrm{y}$. the locus or arc magmatism migrated to an area which included the interarc basin floor and the remnant arc or basin edge. The basin shortly thereafter closed by convergent tectonics during the Nevadan orogeny resulting in the imbrication of the Josephine and Preston Peak ophiolites and their superimposed arc assemblages. The transition from seafloor spreading generation of Josephine ophiolite to its tectonic accretion by convergence and basin closure occurred within 5 to 10 m.y. The process of rifting and ophiolite formation in series with convergence and ophiolite accretion is considered an important mechanism for generating and displacing allocthonous terranes in the Klamath Mountains-Sierra Nevada region, and perhaps throughout the western cordillera.
\end{abstract}

\section{INTRODUCTION}

The Klamath Mountains geological province of northwestern California and southwestern Oregon consists of arcuate fault-bounded belts containing diverse eugeosynclinal assemblages of Paleozoic and Mesozoic age [Irwin, 1960]. Border faults or sutures and distinct structural-stratigraphic features indigenous to each major belt form a basis for their definition. The major belts of the Klamath province are shown in Figure 1; there is a general east to west age progression with rocks as old as early Paleozoic in the east and primarily upper Jurassic rocks in the west. The Klamath belts have been intruded by an array of calc-alkaline affinity plutons of primarily Mesozoic age, and locally they are overlain by Cretaceous strata of the Great Valley sequence [Irwin, 1981]. These assemblages not only contain important petrologic and stratigraphic information, but their age rela-

\footnotetext{
${ }^{1}$ Division of Geological and Planetary Sciences, California Institute of Technology, Pasadena, California 91125.

${ }^{2}$ Department of Geology and Geophysics, University of Utah, Salt Lake City, Utah 84112.

${ }^{3}$ Department of Geology, University of South Carolina, Columbia, South Carolina 29208.

${ }^{4}$ Department of Geology and Geophysics, University of California, Berkeley, California 94720.
}

Copyright 1982 by the American Geophysical Union.

Paper number 2B0050.

0148-0227/82/002B-0050\$05.00 tions place important time constraints on the structural evolution of the Klamath province.

The gross structure of the Klamath province has been interpreted as a structural sequence of east-dipping thrust sheets which are progressively younger to the west [Irwin, 1964; Davis, 1968]. Such a structural configuration of eugeosynclinal terranes has led many workers to speculate that the Klamath province formed by a prolonged history of accretionary events involving the addition of oceanic assemblages onto the North American margin by convergent plate tectonics. The Klamath province is of particular interest with respect to the concept of accretionary tectonics, inasmuch as it was one of the first regions considered to have been produced by the amalgamation of exotic terranes [Hamilton, 1969; Irwin, 1973]. Central to the issue of accretionary tectonics in the Klamaths are the numerous ophiolite fragments which constitute basement remnants of the various eugeosynclinal belts (Figure 1). In this paper, new age data along with published stratigraphic, petrologic, and structural data are discussed for the Josephine and Preston Peak ophiolites and related strata of the west central part of the Klamath Mountains; members of a regional family of crosscutting peridotitic to dioritic intrusive complexes are also discussed. The age relations and the structural-stratigraphic settings of these assemblages will then be discussed in the context of ophiolite formation and emplacement, as well as how these processes relate to Klamath accretionary tectonics. A critical aspect of this paper is the presentation of new 


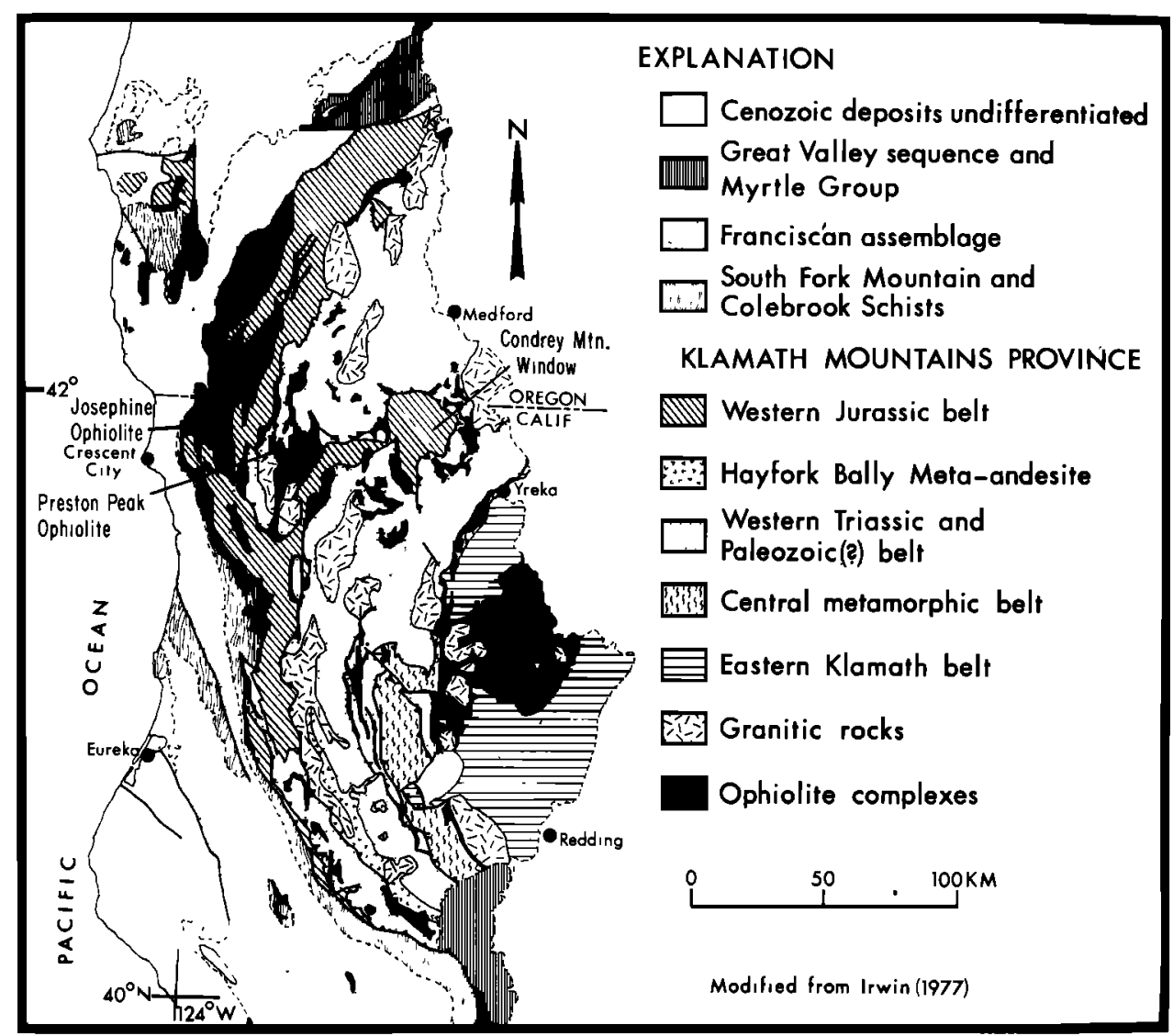

Fig. 1. Generalized geologic map of the Klamath Mountains province, California and Oregon, showing major tectonostratigraphic belts, plutonic masses, Franciscan and related assemblages, and superjacent Cretaceous strata.

$\mathrm{Pb} / \mathrm{U}$ zircon age data which place tight constraints on ophiolite formation and subsequent sedimentation, emplacement, and magmatism.

As shown in Figure 1 the Josephine ophiolite constitutes the basement for the western Jurassic belt in northern California. North of the study area, the basal unit of the ophiolite- the Josephine peridotite-is in thrust contact with volcaniclastic and metaplutonic rocks of the western Jurassic belt [Ramp, 1975; Dick, 1976]. Slaty rocks of the Upper Jurassic Galice Formation constitute the stratified rocks depositionally above the Josephine ophiolite within the study area. The western Jurassic belt marks the western limit of the Klamath province; it is in regional fault contact with the Franciscan Complex of the Coast Ranges to the west. In thrust contact above the western Jurassic belt lies a complex sequence of rock packages which range from late Paleozoic to mid-Jurassic in age. This assemblage was originally named the western Paleozoic and Triassic belt [Irwin, 1960]. However, such an age designation only applies to the ophiolitic basement rocks and scattered limestone blocks [Irwin, 1960; Wright, 1979; Ando et al., 1982]. Radiolarian biostratigraphic studies have shown that the main sequences of stratified rocks in this belt are primarily of Triassic to Early or mid-Jurassic in age [Irwin et al., 1977, 1978; D. L. Jones, personal communication, 1981]. The Preston Peak ophiolite lies along the lowest structural horizon of the western Paleozoic and Triassic belt. This ophiolite is in thrust contact with the Galice Formation of the western Jurassic belt.
The work of Snoke [1977] and Harper [1980a, b] has provided critical field and petrologic data that serve as a basis for the geochronological data presented here, and which will undoubtedly have a significant impact on the concept of accretionary tectonics applied to the Klamath province. Prior to the work of Snoke and Harper it was assumed that the Preston Peak and Josephine ophiolites were successively younger pieces of oceanic crust that were sliced off in a westward stepping subduction zone [Hamilton, 1969]. The data presented here suggest a more complex history involving crustal accretion by ophiolite generation within marginal basin and island arc environments, and the imbrication of such ophiolite fragments by marginal basin closure shortly after its formation. Such processes may be typical of accretionary processes in the North American Cordillera and thus the evolution of the west central Klamath region is of general interest. The most important relations presented in this paper deal with the ages and primary relations within the ophiolite sections. Our discussions will therefore begin with the stratigraphic relations within the ophiolites.

\section{STRATIGRAPHIC RELATIONS}

The map patterns and a generalized cross section of the Josephine and Preston Peak ophiolites and related rocks are shown in Figure 2. The rocks of the study area are divided into two terranes for the purpose of Figure 2. The Josephine terrane consists of the Josephine ophiolite, Galice Formation, and lower Coon Mountain intrusive complex. The 
Preston Peak terrane consists of the Preston Peak ophiolite and adjacent metamorphosed sedimentary and volcanic rocks, and the Bear Mountain intrusive complex. Major structural breaks recognized within the map area are the Preston Peak thrust fault, which is the local expression of the boundary between the western Jurassic and the western Paleozoic and Triassic belts, and the Coast Range thrust. Additional significant breaks may exist between the Preston Peak ophiolite and stratified rocks of the western Paleozoic and Triassic belt, but as discussed below, it is likely that such faults as shown on Figure 2 have only internally disrupted an otherwise coherent terrane. Diagrammatic ophiolite sections have been constructed from the map patterns and from primary mesoscopic relations (Figure 3). These sections also show the overlying metasedimentary rocks and outline the critical radiometric and biostratigraphic age data. The $\mathrm{Pb} / \mathrm{U}$ zircon ages show mainly concordant systematics (Table 1) and are considered igneous crystallization ages. In-depth discussions of zircon concordance and discordance for similar data are given by Saleeby and Sharp [1980] and Saleeby [1982]. The ${ }^{206} \mathrm{~Pb} /{ }^{238} \mathrm{U}$ ages are the most precise, and thus they are used in the text and diagrams. Samples PP582 and J84Z are slightly discordant as a result of the incorporation of xenocrystic zircon from their metasedimentary wallrocks. Such a slight discordance is considered to have had only a minimal effect on the ${ }^{206} \mathrm{~Pb} /{ }^{238} \mathrm{U}$ ages comparable to the analytical uncertainties. This is supported by additional age constraints posed by stratigraphic relations and the other age data (isotopic and biostratigraphic). The $\mathrm{K} / \mathrm{Ar}$ data approximate cooling and/or resetting ages and specific uncertainties are quoted for each sample. The isotopic data are given in Tables 1 and 2 along with information on analytical techniques, uncertainties and age calculations. Descriptions of the field and petrographic settings of the age samples are given in Table 4. The isotopic ages, both igneous and metamorphic, are considered a critical aspect of the stratigraphic picture and thus will be discussed along with the stratigraphic and paleontological relations.

The stratigraphic elements of the Josephine and Preston Peak terranes are grouped below into four assemblages. The ultramafic and mafic sequences of each terrane are considered ophiolite proper [Coleman, 1977]. The Galice Formation of the Josephine terrane constitutes a flysch sequence that was conformably deposited above the Josephine ophiolite. Chert, argillite, epiclastic, and volcanic rocks that are in fault contact with the Preston Peak ophiolite may have formed part of its upper section prior to tectonic disruption, or may belong to a separate terrane. The Josephine ophiolite represents a complete intact sequence, and thus our discussion will begin with it.

\section{Josephine Ophiolite}

The reconstructed Josephine ophiolite section is shown in Figure $3 a$ [after Harper, 1980b]. The base of the section consists of the Josephine peridotite, a harzburgitic tectonite mass with an areal extent of more than $800 \mathrm{~km}^{2}$. Dunite locally forms up to $15 \%$ of the peridotite body and rare orthopyroxenite and gabbroic dikes occur as well. Slickensided serpentinite zones delineate numerous faults internal and peripheral to the peridotite. A tectonite fabric is apparent in many exposures of the peridotite and is defined by elongated trains of chromian spinel and/or by a centimeterscale banding due to variations in the ratio of olivine to orthopyroxene. In thin section, a strong preferred orientation of olivine is apparent from a small difference in birefringence and similar extinction positions of numerous olivine grain:. Kink bands in olivine are very common, and most ortho syroxene grains are kinked or broken. The composition cf olivine and orthopyroxene in harzburgite (estimated by $2 l$ ) is $\mathrm{Fo}_{87-92}$ and $\mathrm{En}_{90-92}$.

Th: Josephine peridotite is an alpine-type peridotite typical of the lower portions of many ophiolites [Coleman, 1977], and is believed to be depleted mantle material presumably linked to the overlying igneous section. A number of studies have focused on the upper mantle history of the peridotite and its involvement in partial melting to yield mafic magma [Himmelberg and Loney, 1973; Dick, 1977; Dick and Sinton, 1979].

Within the area studied, the igneous section of the ophiolite is everywhere in fault contact with the Josephine peridotite, although thick ultramafic cumulate sections adjacent to the peridotite suggest that only a limited amount of displacement has occurred (Figure 2). The base of the igneous section consists of about $1 \mathrm{~km}$ of cumulate wehrlite, clinopyroxenite, and clinopyroxene gabbro with minor orthopyroxenite and lherzolite. The cumulates grade upward into massive isotropic gabbro and diorite characterized by rapid textural changes and complex intrusive breccias. Rare pods of plagiogranite and scattered mafic dikes also occur at this level of the ophiolite. The dikes increase in relative abundance rapidly upwards to form a sheeted dike complex.

Zircon $\mathrm{Pb} / \mathrm{U}$ age data from the Josephine ophiolite are from a plagiogranite pod in the static-textured gabbro-diorite zone and a plagiogranite screen within the sheeted dikes (samples $A 45 Z$ and $A 88 Z$, respectively). Both samples yield concordant $157 \mathrm{~m} . \mathrm{y} . \mathrm{Pb} / \mathrm{U}$ ages (Table 1). Contradictory intrusive relations with mafic dikes of the ophiolite constrain the magmatic emplacement of the plagiogranite bodies to within the igneous history of the ophiolite. Thus the $157 \mathrm{~m} . \mathrm{y}$. zircon ages of samples $\mathrm{A} 45 \mathrm{Z}$ and $\mathrm{A88Z}$ are considered to be the igneous age of the ophiolite. The importance of these data with respect to the overall stratigraphic framework will be discussed below.

The sheeted dike complex grades abruptly upward into basaltic pillow lava as much as $400 \mathrm{~m}$ thick with lesser isolated and broken pillow breccia. Local screens of the pillow sequence occur in the upper dike complex and isolated dikes and sills extend well into the pillow section. The pillow and high-level intrusive sequences of the Josephine ophiolite encompass a metamorphic gradient which ranges downward from prehnite-pumpellyite to amphibolite facies. Metamorphic mineral growth occurred under static conditions with high fluid mobility of alkalies, and represents the vestiges of ocean floor hydrothermal metamorphism which occurred at the site of ophiolite genesis [Coleman, 1977].

The Josephine ophiolite as exposed in the study area represents a complete ophiolite sequence. The great mass of depleted mantle-type rock beneath the igneous section which contains a well-developed sheeted dike complex overlain by pillow basalt points to an origin by seafloor spreading processes. Zircon ages of $157 \mathrm{~m} . \mathrm{y}$. are considered the seafloor spreading genesis age of the ophiolite. The paleogeographic setting of this seafloor spreading is recorded in the upper Jurassic Galice Formation which lies depositionally above the ophiolite pillow lava section. 

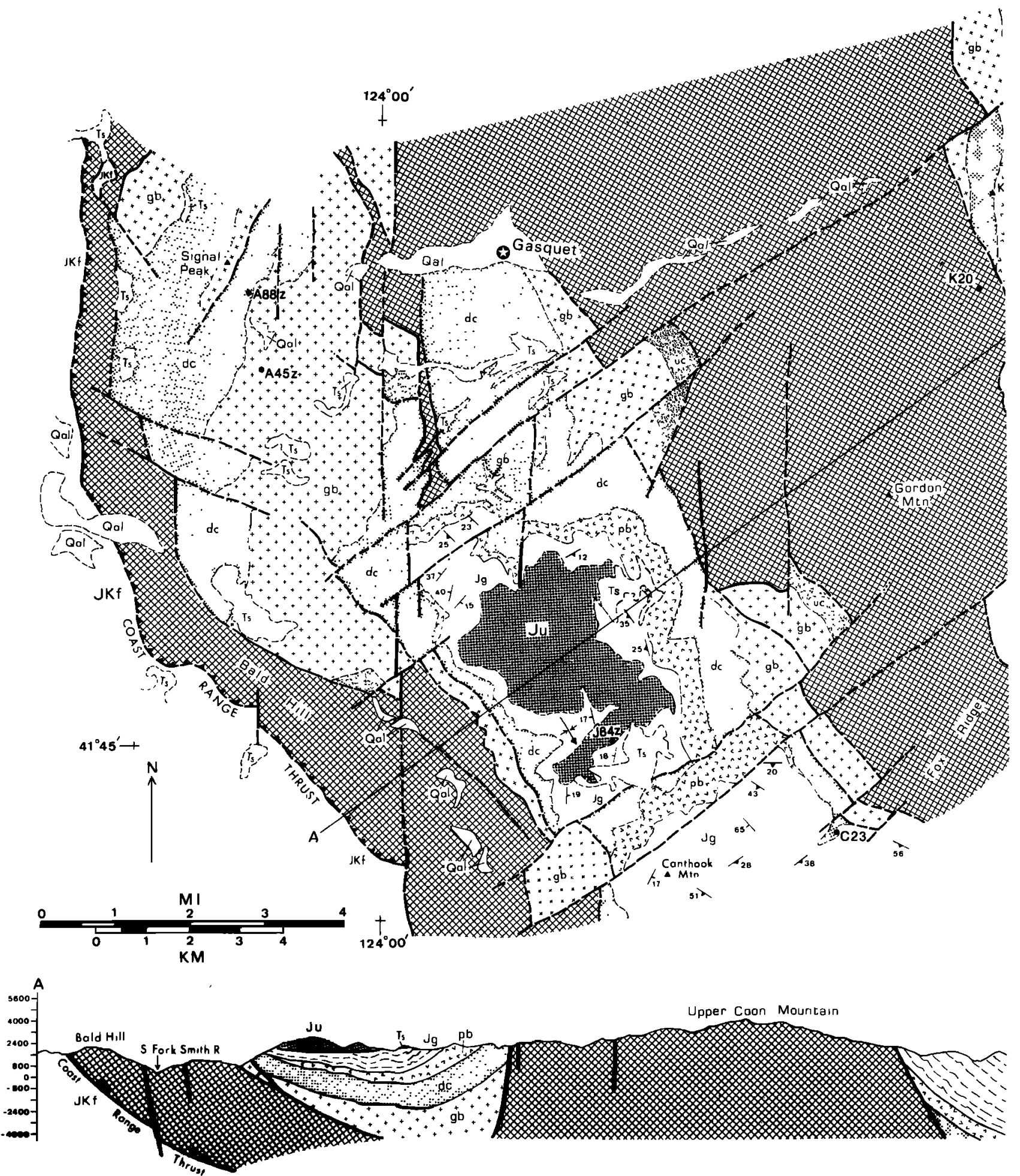

Fig. 2. Geologic map and cross section of the area covered in this report. Geochronological sample locations also shown. Explanation for Figure 2 is on overleaf of adjacent page.

\section{Galice Formation}

A thin hemipelagic sequence consisting of chert and slate conformably overlies the Josephine ophiolite, and is in turn overlain by a thick flysch sequence of interbedded slate, metagreywacke, and rare pebble conglomerate. The hemipelagic sequence consists of up to $35 \mathrm{~m}$ of thinly bedded green chert, black slate, and locally red metalliferous slate. Abun- dant 'ghosts' of radiolaria are apparent in thin sections of cherts and some interbedded slates. Small amounts of green chert also occur as interpillow sediment in underlying lavas of the ophiolite. Radiolaria from the basal chert range tentatively from Callovian to Oxfordian in age (D. L. Jones, personal communication, 1981). A depositional contact between pillow lava of the ophiolite and the Galice hemipelagic sequence is well exposed on the Middle Fork of the Smith 


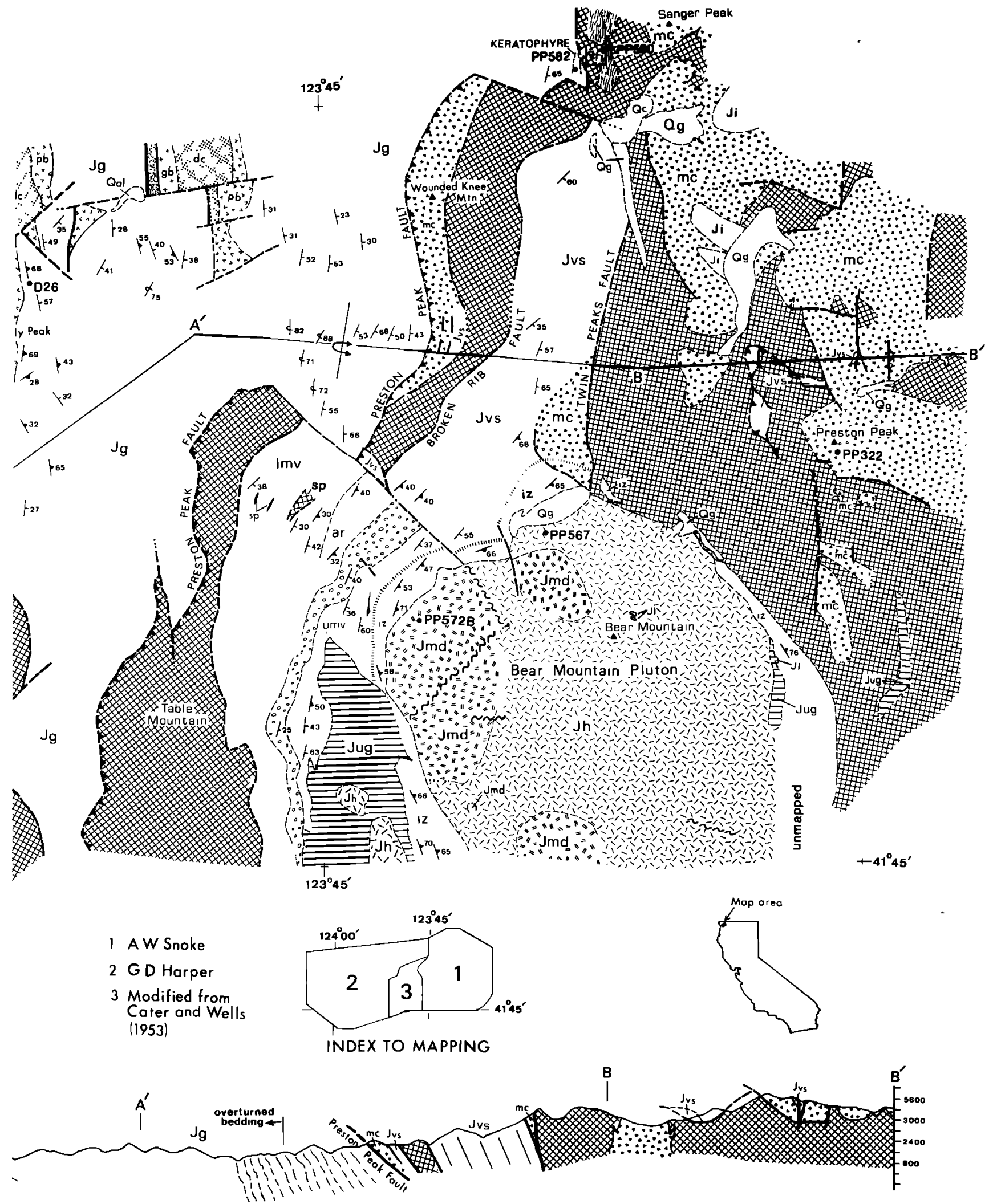

Fig. 2. (continued)

River near the mouth of Little Jones Creek [Harper, 1980a, Figure G-1].

The hemipelagic sequence is overlain by and locally interbedded with terrigneous clastic material of the flysch sequence. Graded beds, rip-up clasts, planar beds and ripple cross stratification are common, and load and flame structures as well as sole marks are locally abundant. Several different facies are recognized within the flysch, and Harper [1980a] has compared these to submarine fan facies of Mutti and Ricci-Lucchi [1972], Walker and Mutti [1973], and 


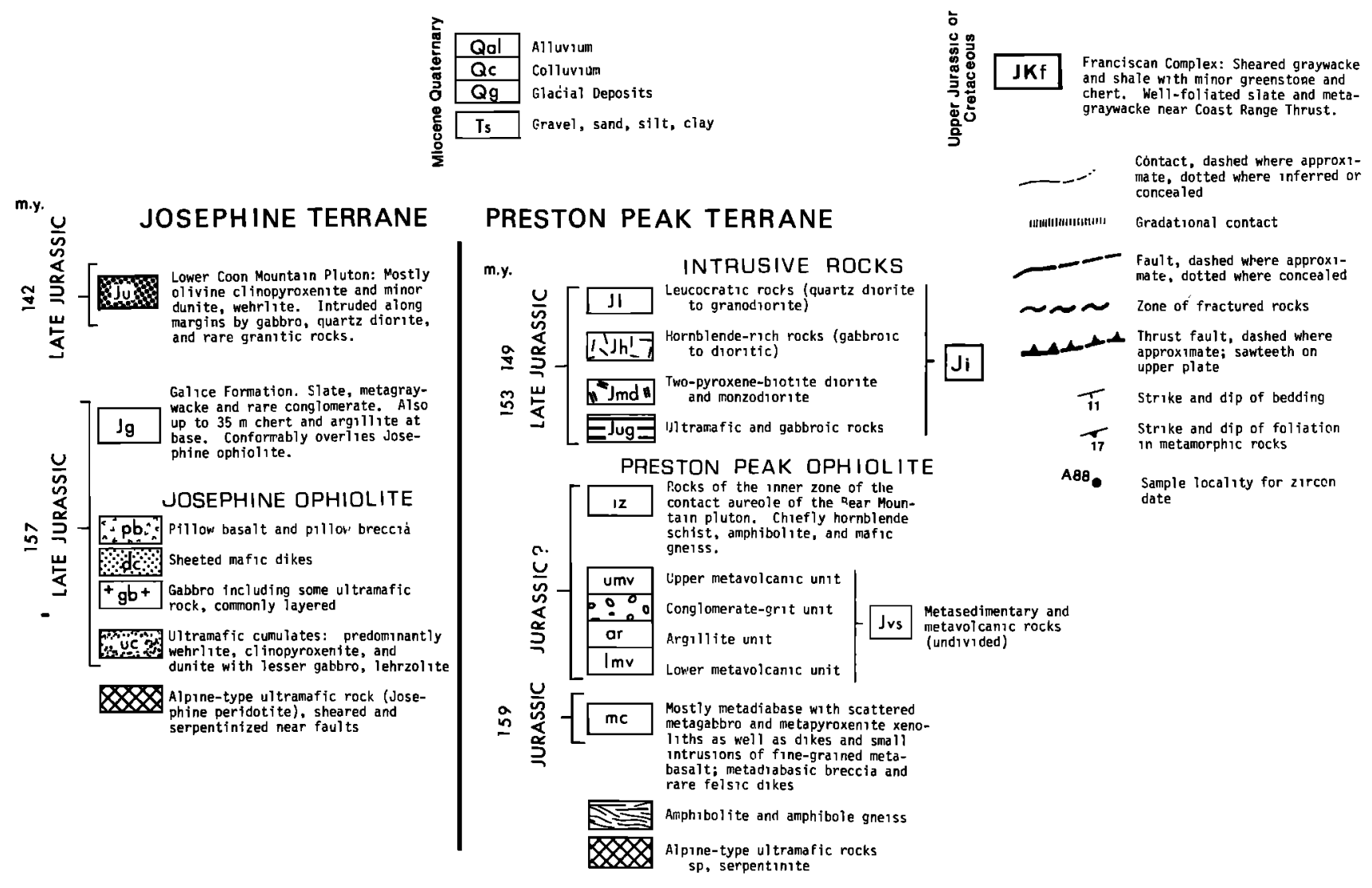

Fig. 2. (continued)

Ingersoll [1978]. The most common facies recognized include channel and overbank deposits, and abundant mid-fan to outer-fan deposits. The thickness of the Galice Formation cannot be determined accurately because of structural thickening by faulting and folding. The large outcrop area suggests a thickness of several kilometers.

Metagreywackes of the Galice flysch are characterized by a weak to strong cleavage, and a well-developed slaty cleavage is ubiquitous in pelitic rocks. Sedimentary structures and textures are well preserved except in areas of intense deformation and recrystallization. At the highest structural level of the flysch sequence, adjacent to the Preston Peak thrust, lies a volcaniclastic interval of about $150 \mathrm{~m}$ thickness. A quartz keratophyre sill-like intrusion which cuts the volcaniclastic rocks [Snoke, 1977, Figure 8] has yielded a concordant $150 \mathrm{~m}$.y. zircon age (sample PP582, Table 1). The volcaniclastic rocks are moderately cleaved while the keratophyric intrusion lacks cleavage but is internally deformed and highly fractured. A similar $151 \mathrm{~m} . \mathrm{y}$. zircon age (sample C23, Table 1) was obtained on a strongly foliated meta-dacite dike which cuts the upper part of the ophiolite and is one of numerous, primarily intermediatecomposition dikes which cut the ophiolite and the lower levels of the Galice Formation. A hornblende andesite dike of a dike swarm within the Josephine peridotite yielded a K/Ar hornblende age of $147 \pm 6 \mathrm{~m}$.y. (sample K20, Table 2). These ages are in agreement with $\mathrm{K} / \mathrm{Ar}$ dates obtained by Dick [1973, 1976] which cluster between 145 to $150 \mathrm{~m}$.y. for lithologically similar dikes which intrude the Josephine peridotite north of the study area.

Fossils from the Galice metasedimentary sequence were collected by J. S. Diller of the U.S. Geological Survey from several localities about $10 \mathrm{~km}$ north of the study area. Harper [1980a] located one of these localities and found that the fossils (bivalves) occur in a pebble conglomerate bed stratigraphically near the base of the flysch sequence. The fossils were identified by D. L. Jones (personal communication, 1979) as Buchia concentrica (Sowerby), which ranges from late Oxfordian to early Kimmeridgian [Imlay, 1959]. The upper age limit of the Galice Formation is constrained to $150 \mathrm{~m} . \mathrm{y}$. by the zircon date of the quartz keratophyre intrusion and by regional metamorphism (Nevadan Orogeny), also dated at about $150 \mathrm{~m} . \mathrm{y}$. on Galice metagreywacke from south of the study area [Lanphere et al., 1978]. Thus the absolute age of the Galice Formation in the study area is tightly constrained to between $157 \mathrm{~m}$.y. (age of the Josephine ophiolite) and $150 \mathrm{~m} . \mathrm{y}$.

The Galice sandstone beds consist primarily of lithic wackes and feldspatholithic wackes [Harper, 1980a]. The chief detrital constituents include volcanic rock fragments, plagioclase, chert, argillite, monocrystalline quartz, and rare metamorphic rock fragments. The lower stratigraphic levels are enriched in volcanic rock fragments and plagioclase, whereas the main part of the section contains primarily chert and siliceous argillite clasts with lesser volcanic fragments and plagioclase. A gradation exists between volcanic-rich and volcanic-poor sandstones. Chert pebbles are common throughout the flysch sequence in pebble conglomerates and along pebbly bases of graded sandstone beds. Radiolaria ghosts are common in such pebbles as they are in chert sand grains. Triassic radiolaria (identified by D. L. Jones, 1980) were extracted from chert pebbles in the study area near 


\section{A. JOSEPHINE}

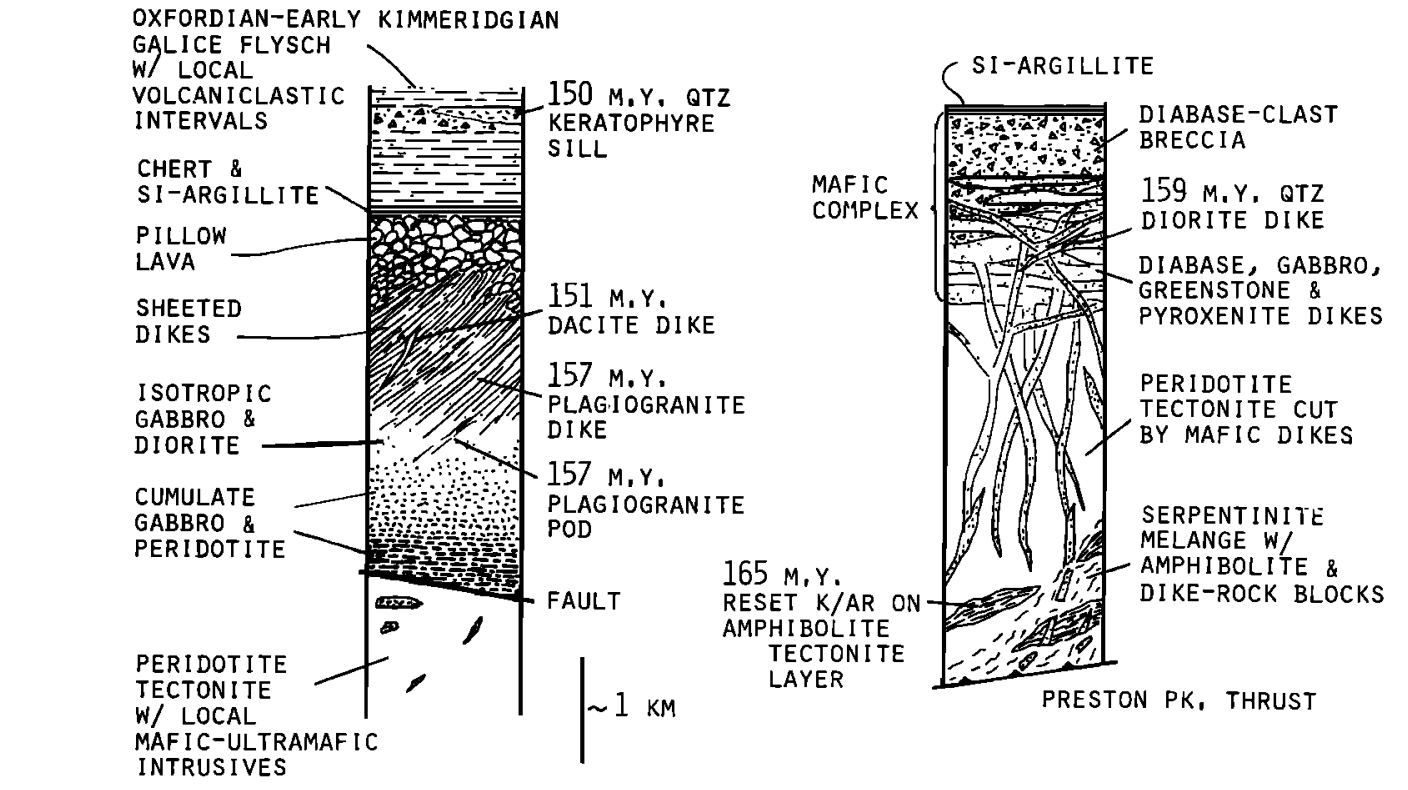

\section{B. PRESTON PEAK}

Fig. 3. Diagrammatic stratigraphic sections for (a) the Josephine ophiolite and Galice Formation [Harper, 1980a, b] and $(b)$ the Preston Peak ophiolite [Snoke, 1977]. Also shown are critical age data.

Baker Flat and from Galice beds to the north of the area in the vicinity of Galice Creek, southwest Oregon. Heavy minerals were identified in thin sections of sandstones and heavy mineral separates, and include zircon, tourmaline, chromian spinel, garnet, sphene, apatite, muscovite, biotite, blue amphibole, and staurolite. In addition, abundant clinopyroxene and lesser hornblende, both of which commonly occur as phenocrysts in volcanic rock fragments, are present in the basal volcanic-rich sandstones.

Two source terranes are evident for the Galice sandstone beds-a volcanic source and a metamorphic-ophiolitic-hemipelagic source. The following characteristics of the detrital constituents imply that the volcanic source was a magmatic arc:

1. Compositions of volcanic rock fragments indicate a predominance of intermediate-type volcanics.

2. Porphyritic textures, which are common in the volcanic rock fragments, are characteristic of lavas erupted in modern magmatic arcs [Ewart, 1976].

3. The volcanic source terrane also supplied phenocrystic plagioclase and minor quartz, pyroxene, and hornblende which are typical of magmatic arcs.

4. Volcanic-enriched sandstones which occur in the highest structural level of the Galice are intimately related with intermediate composition volcaniclastic rocks of magmatic arc affinity.

The second source terrane of the Galice Formation was comprised primarily of chert and siliceous argillite (pelagic and hemipelagic sediments) which was at least partly Triassic in age. This source terrane also included metamorphic rocks which yielded metaquartzite and phyllite lithic fragments, and heavy mineral assemblages consisting of mica, garnet, staurolite, and blue amphibole. Well-rounded zircon and rare quartzose sandstone clasts have also been observed and indicate erosion of mature sandstones. Chromium spinel grains are common and imply ultramafic sources, suggesting the presence of ophiolitic rocks in the source terrane.

As suggested by Snoke [1977], very likely sources for the detritus in Galice sandstones are older terranes of the Klamath Mountains, exposed to the east. Such an interpretation is also consistent with the available paleocurrent data which show generally westward sediment transport [Harper, $1980 a$ ]. Chert and argillite are common rock types of the western Paleozoic and Triassic belt [Irwin, 1966, 1977], much of which has been recently dated by radiolaria as Triassic and Jurassic [Irwin et al., 1977, 1978]. Suitable source rocks for the metamorphic detritus include parts of the central metamorphic belt and high grade rocks of the western Paleozoic and Triassic belt [Davis, 1968; Hotz et al., 1977; Medaris et al., 1980; Hanks, 1981]. Quartz-rich sandstone clasts and recycled zircon may have been derived from Paleozoic rocks in the eastern Klamath Mountains [Potter et al., 1977], from quartzose sandstones of the Hayfork terrane-a subdivision of the Western Paleozoic and Triassic belt [Irwin, 1972, 1977; Wright, 1980], or from Paleozoic quartzose flysch in the northern Sierra Nevada [Bond and DeVay, 1979]. Ophiolitic rocks that may have supplied chromium spinel are widespread in the Klamath Mountains and may include part of the Preston Peak complex.

A wide range of possibilities exist for the volcanic source of the Galice sandstones. In the type area of the Galice Formation in southern Oregon, Galice beds lie above a thick sequence of basaltic to rhyolitic tuffs, breccias and flows of the Rogue Formation [Wells and Walker, 1953; Garcia, 1979], and volcaniclastic rocks occur in depositional contact beneath Galice beds in the Willow Creek area south of the study area [Young, 1978]. Thus volcanic detritus locally derived from the western Jurassic belt may have been contributed to the lower volcanic rich sands of the Galice in the study area. Possible volcanic source areas to the east of 
the study area include the Hayfork volcaniclastic strata and cross-cutting 163 to $170 \mathrm{~m} . y$. plutons which occur in the Western Paleozoic and Triassic belt [Irwin, 1972; Wright, 1980]. Or a more proximal source could be upper parts of the Preston Peak ophiolite and possible eruptive equivalents of the Bear Mountain pluton, both discussed below. Furthermore, the Galice volcaniclastic interval in the study area and 150 and $151 \mathrm{~m} . \mathrm{y}$. intermediate composition dikes and sills which cut the Josephine-Galice section demonstrate the existence of proximal volcanic arc activity at least during the later stages of Galice deposition. In conclusion, Jurassic and older rock units of the Klamath province contain all of the essential components to yield the Galice detritus, and thus it is reasonable to assume that Galice deposition occurred in general proximity to the older previously accreted Klamath terranes.

\section{Significance of Primary Relations Between Josephine Ophiolite and Galice Formation}

Although ophiolite complexes are widely regarded as fragments of ancient oceanic crust and upper mantle, it is becoming increasingly apparent that many of these maficultramafic complexes probably did not originate at midocean spreading centers. For example, basalts and diabases from ophiolites are commonly petrologically and geochemically different from mid-ocean ridge basalts, even when alteration is taken into account [Smewing et al., 1975; Hodges, 1976; Evarts, 1977; Upadhyay and Neale, 1979]. In addition, evidence from regional geologic relationships and overlying sedimentary sequences indicates that many ophiolites were generated in proximity to island arcs. These features have lead a number of workers to suggest that some ophiolites formed within marginal basins in proximity to island arcs rather than at mid-ocean ridges [Dalziel et al., 1974; Evarts, 1977; Kidd, 1977; Xenophontos and Bond, 1978; Upadhyay and Neale, 1979; Saleeby, 1981, 1982].

The Josephine ophiolite section contains all of the elements considered diagnostic of the generation of juvenile oceanic crust by seafloor spreading. However, the conformable depositional contact of the Galice Formation above the ophiolite clearly indicates that such seafloor spreading occurred adjacent to an active volcanic arc and uplifted continental margin orogenic assemblages. Upper Jurassic intermediate composition dikes which cut the ophiolite and Galice Formation further demonstrate ophiolite generation in proximity to an active volcanic arc terrane. The tight clustering of zircon ages, 157 m.y. for the ophiolite and 150 and $151 \mathrm{~m} . y$. for the intermediate composition dikes, place tight time constraints on the evolution of the JosephineGalice section. Such constraints further show that Galice deposition followed immediately after ophiolite generation, and that such deposition occurred within the same paleogeographic regime as the ophiolite generation.

Generation of the Josephine ophiolite and deposition of the Galice Formation are considered to have occurred in a marginal or interarc basin as suggested by Snoke [1977], Vail [1977], and Harper [1980a, b]. Zircon age data presented in this paper further substantiate these views. Our discussion turns next to the Preston Peak ophiolite and related rocks, and then to their possible relations to the Josephine-Galice section.

\section{Preston Peak Ophiolite}

The Preston Peak ophiolite section is shown diagrammatically in Figure $3 b$ [after Snoke, 1977]. The outstanding feature of this ophiolite is a clear polygenetic origin. The ultramafic tectonites have a deformational and metamorphic history which predates the generation of the upper mafic complex. Furthermore, dikes of the mafic complex crosscut the tectonites demonstrating that the upper part of the section was superimposed over an older unroofed ultramafic basement.

The ultramafic basement complex chiefly consists of serpentinized tectonitic harzburgite; dunite and lherzolite are subordinate. The ultramafic rocks display a wide range of metamorphic textures ranging from coarsely recrystallized massive peridotite to well-foliated mylonitic rocks [Snoke, 1977]. Much of the original mineralogy and texture has been obliterated by serpentinization. Concordantly interlayered with the ultramafic tectonites are inclusions of amphibolite facies mafic tectonite. These are presumably fragments of oceanic crustal material that were tectonically interlayered with the ultramafic rocks during the main metamorphicdeformation event.

Mafic dikes crosscut the ultramafic and mafic tectonites. These dikes are similar in composition to diabasic hypabyssal rocks of the mafic complex which lie above the tectonites. The cross-cutting dikes are considered to be feeders for the mafic complex. Not only do the contrasting deformational histories between the tectonites and mafic intrusives point to a hiatus in the development of the ophiolite, but the ultramafic tectonites underwent a complex alteration history prior to and during dike emplacement. This is shown by cross-cut hydrothermally altered metaserpentinites (jackstraw-textured talc-olivine rocks [Snoke and Calk, 1978]), which indicate serpentinization of the tectonites prior to dike emplacement followed by hydrothermal metamorphism presumably related to the diking event. Thus the Preston Peak tectonites underwent a severe deformation-metamorphic history and were further disrupted during serpentinization prior to the injection of mafic dikes and the construction of the mafic complex.

The mafic complex consists primarily of diabase and diabase breccia with lesser gabbro, clinopyroxenite and greenstone dike rock; all showing low-greenschist facies static metamorphism. Such a static overprint may represent autometamorphism with gross similarities to sea floor metamorphism. Screens of altered ultramafic tectonite occur locally within the mafic complex along an edge zone facies that is transitional with the older basement complex. The diabasic intrusive sequence consists of multiple intrusions of primarily dike-like bodies having chilled margins. The intrusive sequence is on the order of 1 to $2 \mathrm{~km}$ in thickness. It grades rapidly upwards into diabase breccia. Along the transition zone diabasic dikes are interlayered with the breccia.

The diabasic breccia is about $500 \mathrm{~m}$ in thickness. It consists primarily of 1 to $10 \mathrm{~cm}$ scale angular diabase and massive greenstone clasts with rare gabbroic clasts. Sorting is extremely poor with some clasts ranging up to $30 \mathrm{~cm}$ in diameter. The breccia is clast supported with mafic grit filling interstices. Above the breccia lies a thin cap of siliceous argillite [Snoke, 1977]. 
The Preston Peak ophiolite possesses internal structuralstratigraphic relations which differ markedly from the concept of an ideal ophiolite section [Coleman, 1977]. The ultramafic tectonites clearly do not represent mantle residue left behind from the melting event which gave rise to the overlying mafic complex. Furthermore, a well-developed cumulate sequence is lacking, the hypabyssal sequence lacks sheeted dikes, and the uppermost mafic rocks consist of breccia rather than pillow lava. The Preston Peak ophiolite clearly does not represent juvenile oceanic crust created at a spreading center. On the basis of major and trace element data including rare earth elements [Snoke et al., 1977], and clinopyroxene phase chemistry [Snoke and Whitney, 1979] it is suggested that the mafic complex represents a primitive island arc-related tholeiitic assemblage. This is in concert with Snoke's [1977] original suggestions based on field relations for a polygenetic origin of the ophiolite entailing the construction of a primitive island arc assemblage across older disrupted and metamorphosed mafic-ultramafic basement. The diabase breccia is considered to be the product of near-vent pyroclastic activity or alternatively talus from a submarine fault-scarp. The mafic intrusive sequence constitutes a subvolcanic feeder system or alternatively a hypabyssal complex unroofed by submarine faulting.

Age constraints on the mafic complex place it at about 160 m.y. These constraints are the concordant $\mathrm{Pb} / \mathrm{U}$ zircon age of 159 m.y. (sample PP322, Table 1) on a late-stage Na-rich quartz diorite dike within the intrusive sequence, and a 165 m.y. reset K/Ar amphibole age (sample PP580, Table 2) on an amphibolite tectonite of the basement complex which shows a clear static textural overprint with retrograde mineral assemblages. The zircon data must be taken as a minimum age, although the metamorphic and alteration features of the quartz diorite dike along with the restriction of such rocks to the mafic complex suggest that it was part of the complex. The reset amphibolite is far removed from the contact effects of the Bear Mountain intrusive complex (Figure 1) or any other post ophiolite intrusives. It is in proximity to the mafic complex, and isolated dikes of the complex actually crosscut the amphibolite. Thus the reset $\mathrm{K} / \mathrm{Ar}$ amphibole age is also considered a rough approximation for the age of the mafic dikes.

Numerous slices of tectonitic peridotite, serpentinite, and mafic tectonite occur along with fragmented ophiolite sections in the western Paleozoic and Triassic belt. Some of the ophiolitic fragments are known to be of late Paleozoic and early Mesozoic age [Wright, 1979; Ando et al., 1982] and are considered to be oceanic basement for the Mesozoic chertargillite and volcaniclastic sequences of the belt. The tectonitic basement complex of the Preston Peak ophiolite is considered to be such a basement fragment.

\section{Stratified Rocks Associated With the Preston Peak Ophiolite}

An undated sequence of metamorphosed mafic volcanic rock, chert, argillite, greywacke, conglomerate, and rare limestone occurs in fault contact with rocks of the Preston Peak ophiolite [Snoke, 1977]. The metavolcanic rocks are similar to rocks of the ophiolite's mafic complex, and siliceous argillite within the sequence is similar to siliceous argillite that caps the mafic complex of the ophiolite. Whether the stratified rocks represent part of the upper sequence within the Preston Peak ophiolite, or are part of some other terrane in the western Paleozoic and Triassic belt is unclear.

TABLE 1. Zircon Isotopic Data

\begin{tabular}{|c|c|c|c|c|c|c|c|c|c|c|c|}
\hline \multicolumn{3}{|c|}{ Sample Data* } & \multicolumn{2}{|c|}{$\begin{array}{l}\text { Concentra- } \\
\text { tions } \dagger\end{array}$} & \multicolumn{3}{|c|}{$\begin{array}{l}\text { Isotopic Composi- } \\
\text { tions }\end{array}$} & \multicolumn{3}{|c|}{ Ages, m.y.§ } & \multirow[b]{2}{*}{ Rock Type } \\
\hline $\begin{array}{l}\text { Sample } \\
\text { Number }\end{array}$ & $\begin{array}{l}\text { Fraction } \\
\text { Properties }\end{array}$ & $\begin{array}{c}\text { mg } \\
\text { Analyzed }\end{array}$ & ${ }^{\mathrm{ppm}}$ & ${ }_{206 \mathrm{~Pb}}^{\mathrm{ppm}}$ & ${ }^{206} \mathrm{~Pb} /$ & $\begin{array}{l}{ }^{206} \mathrm{~Pb} / \\
{ }^{207} \mathrm{~Pb}\end{array}$ & $\begin{array}{l}{ }^{206} \mathrm{~Pb} / \\
{ }^{208} \mathrm{~Pb}\end{array}$ & $t \frac{{ }^{206} \mathrm{~Pb} \ddagger}{{ }^{238} \mathrm{U}}$ & $t \frac{{ }^{207} \mathrm{~Pb} \ddagger}{{ }^{235} \mathrm{U}}$ & $t \frac{{ }^{207} \mathrm{~Pb} \ddagger}{206 \mathrm{~Pb} \ddagger}$ & \\
\hline PP322 & $\begin{array}{l}1.7 \text { A } 5 / 20 \\
\mathrm{~nm} 1 / 20 \mathrm{~m}<80 \mu\end{array}$ & 12.0 & 422 & 9.1 & 1556 & 16.99 & 2.099 & $159 \pm 2$ & $159 \pm 2$ & $167 \pm 10$ & $\begin{array}{l}\text { quartz diorite from } \\
\text { Prestón Peak ophiolite }\end{array}$ \\
\hline \multirow[t]{2}{*}{ A45Z } & $\begin{array}{l}1.7 \text { A } 5 / 20 \\
\mathrm{~nm}<165 \mu\end{array}$ & 23.5 & 717 & 15.3 & 5200 & 19.40 & 0.916 & $157 \pm 2$ & $158 \pm 2$ & $168 \pm 10$ & $\begin{array}{l}\text { plagiogranite from } \\
\text { Josephine ophiolite }\end{array}$ \\
\hline & replicate & 17.0 & 685 & 14.7 & 1553 & 16.99 & 0.882 & $158 \pm 2$ & $159 \pm 2$ & $167 \pm 10$ & \\
\hline A88Z & $\begin{array}{l}1.7 \text { A } 5 / 20 \\
\mathrm{~nm}<165 \mu\end{array}$ & 12.4 & 787 & 16.8 & 1135 & 16.08 & 2.932 & $157 \pm 2$ & $157 \pm 2$ & $159 \pm 10$ & $\begin{array}{l}\text { plagiogranite from } \\
\text { Josephine ophiolite }\end{array}$ \\
\hline $\mathrm{C} 23$ & $\begin{array}{l}1.7 \text { A } 10 / 25 \\
\mathrm{~nm}<80 \mu\end{array}$ & 5.2 & 175 & 3.6 & 191 & 7.90 & 2.720 & $151 \pm 3$ & $152 \pm 3$ & $169 \pm 25$ & $\begin{array}{l}\text { dacite dike intruding } \\
\text { Josephine ophiolite }\end{array}$ \\
\hline PP572B & $\begin{array}{l}1.8 \text { A } 10 / 20 \mathrm{~nm} \\
0.5 / 20 \mathrm{~m} 80-45 \mu\end{array}$ & 10.7 & 236 & 4.9 & 704 & 14.34 & 4.664 & $153 \pm 2$ & $153 \pm 2$ & $142 \pm 13$ & $\begin{array}{l}\text { pyroxene diorite- } \\
\text { Bear Mtn. complex }\end{array}$ \\
\hline \multirow[t]{2}{*}{ PP567 } & $\begin{array}{l}1.7 \text { A } 10 / 20 \\
\mathrm{~nm} 80-45 \mu\end{array}$ & 10.3 & 151 & 3.1 & 2395 & 18.19 & 7.028 & $149 \pm 2$ & $149 \pm 2$ & $140 \pm 10$ & $\begin{array}{l}\text { hornblende diorite- } \\
\text { Bear Mtn. Complex }\end{array}$ \\
\hline & $\begin{array}{l}1.7 \text { A } 10 / 20 \\
\text { nm } 120-80 \mu\end{array}$ & 23.3 & 151 & 3.1 & 3118 & 18.75 & 7.058 & $150 \pm 2$ & $150 \pm 2$ & $158 \pm 10$ & \\
\hline PP582 & $\begin{array}{l}1.7 \text { A } 3 / 20 \\
\mathrm{~nm}<120 \mu\end{array}$ & 11.0 & 467 & 9.51 & 1000 & 15.60 & 3.093 & $150 \pm 2$ & $151 \pm 2$ & $167 \pm 10$ & $\begin{array}{l}\text { quartz keratophyre } \\
\text { sill in Galice }\end{array}$ \\
\hline J84Z & $\begin{array}{l}1.0 \text { A } 10 / 25 \\
\mathrm{~nm}<165 \mu\end{array}$ & 5.2 & 905 & 17.4 & 1918 & 17.58 & 6.684 & $142 \pm 2$ & $142 \pm 2$ & $159 \pm 10$ & $\begin{array}{l}\text { granodiorite-lower } \\
\text { Coon Mtn. complex }\end{array}$ \\
\hline
\end{tabular}

*nm, nonmagnetic fraction; m, magnetic fraction; 10/25, degrees of side and front slopes, respectively, on Franz isodynamic separator. †Chemical processing by methods similar to those of Krogh [1973] with minor modifications [Saleeby and Sharp, 1980].

$¥$ Radiogenic lead with nonradiogenic correction of 204:206:207 $=1: 18.6: 15.6$.

§Decay constants: $\lambda\left({ }^{238} \mathrm{U}\right)=1.5513 \times 10^{-10} ; \lambda\left({ }^{235} \mathrm{U}\right)=9.8485 \times 10^{-10} \mathrm{yr}{ }^{-1} ;{ }^{235} \mathrm{U} /{ }^{238} \mathrm{U}=137.8$.

Uncertainties in $\mathrm{Pb} / \mathrm{U}$ ages based on uncertainties in ${ }^{206} \mathrm{~Pb}$ and ${ }^{238} \mathrm{U}$ concentration determinations and on long-term reproducibility of ages. Uncertainties in ${ }^{207} \mathrm{~Pb} /{ }^{206} \mathrm{~Pb}$ ages based on reproducibility in NBS983 standard, common $\mathrm{Pb}$ uncertainty (including effect of ${ }^{206} \mathrm{~Pb} /$ ${ }^{204} \mathrm{~Pb}$ ), and on history of agreement in ${ }^{207} \mathrm{~Pb} /{ }^{206} \mathrm{~Pb}$ ages between spiked and unspiked aliquots. 
TABLE 2. K/Ar Isotopic Data

\begin{tabular}{lcccccc}
\hline $\begin{array}{c}\text { Sample } \\
\text { Number }\end{array}$ & $\begin{array}{c}\text { Sample } \\
\text { Weight, } \mathrm{g}\end{array}$ & $\% \mathrm{~K}$ & $\begin{array}{c}{ }^{40} \mathrm{Ar} \text { Radiogenic } \\
\text { moles/g } \times 10^{-11}\end{array}$ & $\%^{40} \mathrm{Ar}$ & $\begin{array}{c}\text { Age, } \\
\mathrm{m.y} .\end{array}$ & Rock Type \\
\hline PP580 & 0.80171 & 0.1384 & 4.147 & 43.4 & $165 \pm 3$ & $\begin{array}{c}\text { retrograded amphibolite } \\
\text { tectonite in Preston } \\
\text { Keak ophiolite }\end{array}$ \\
K20 & 0.60036 & 0.2495 & 6.605 & 50.7 & $147 \pm 6$ & $\begin{array}{c}\text { hornblende andesite } \\
\text { dike in Josephine } \\
\text { peridotite } \\
\text { hornblende andesite } \\
\text { dike in Galice } \\
\text { Formation }\end{array}$ \\
\hline
\end{tabular}

Analytical techniques after Dalrymple and Lanphere [1969]. Decay constants: $\lambda_{40 \mathrm{~K}_{\beta}}=4.962 \times$ $10^{-10} / \mathrm{yr} ; \lambda_{40} \mathrm{~K}^{e}+\lambda^{\prime}{ }_{40} \mathrm{~K}^{e}=0.581 \times 10^{-10} / \mathrm{yr}$. Isotopic abundance: ${ }^{40} \mathrm{~K}=0.01167 \% \mathrm{~K}_{\mathrm{total}}$.

These strata lack the metamorphic-deformational features which occur in the tectonitic basement of the ophiolite, and we have found that similar strata from Greyback Mountain located $10 \mathrm{~km}$ north of the study area contain Jurassic radiolaria (D. L. Jones, written communication, 1981). Field relations between the Greyback Mountain strata and stratified rocks more closely related to the Preston Peak ophiolite have yet to be resolved.

\section{Summary of Stratigraphic Relations}

The Josephine-Galice section constitutes juvenile oceanic crust created at about 157 m.y. by seafloor spreading. Ophiolite formation was directly followed by hemipelagic and submarine fan sedimentation, and intermediate volcaniclastic sedimentation and diking no later than $150 \mathrm{~m}$.y. The source area for the Galice submarine fan was probably the pre-Jurassic terranes of the Klamath region including the neighboring western Paleozoic and Triassic belt.

The Preston Peak ophiolite represents a roughly 160 m.y. mafic igneous complex which was constructed on an older unroofed mafic-ultramafic basement fragment belonging to the western Paleozoic and Triassic belt. Deposition of nearvent pyroclastic breccias or submarine fault-scrap breccias accompanied the growth of a mafic hypabyssal complex. Deposition of the breccia was terminated abruptly as it was capped by a thin hemipelagic sequence. Thicker sequences of mafic volcanic rock, chert, and argillite associated with the Preston Peak ophiolite may have been constructed along with the mafic hypabyssal and breccia complex, or alternatively they represent fragments of older Middle or Lower Jurassic strata that are common throughout the western Paleozoic and Triassic belt.

A fundamental question is the relationship between the coeval but petrogenetically distinct Josephine and Preston Peak ophiolites. This is a question in the tectonics of both ophiolite formation and emplacement and requires as many constraints as possible. Additional constraints are derived from the fold-thrust history of the ophiolites, and from igneous rocks which crosscut the ophiolite terranes.

\section{Folding ANd Thrusting of The Josephine-Preston Peak Sections}

The Josephine terrane is apparently an east-dipping thrust plate. On the east it forms the lower sheet beneath the Preston Peak fault, interpreted by Snoke [1977] to be an eastdipping thrust fault that moved during late Jurassic time. This thrust places the Preston Peak terrane and strata of the western Paleozoic and Triassic belt above the Galice Forma- tion (Figure 2), and thus it appears to be the local expression of a regional tectonic boundary. The Josephine terrane is bounded on the west by a moderately dipping fault interpreted to be the unturned edge of the regional Coast Range thrust fault. The Coast Range thrust separates the Klamath and Great Valley provinces to the east from the Coast Range province to the west. In most places the Coast Range thrust separates Middle to Upper Jurassic ophiolite with overlying Upper Jurassic mudstone from the Franciscan Complex [Bailey et al., 1970].

The Josephine terrane plate has been subjected to two main phases of deformation [Harper, 1980a]: (1) Late Jurassic (Nevadan orogeny) folding, slaty-cleavage development and prehnite-pumpellyite to lower greenschist facies metamorphism best developed in Galice Slate; and (2) PostNevadan open folding and kinking apparently not accompanied by metamorphism, and possible high-angle faulting along the trace of the Preston Peak thrust. The Galice Formation experienced a much greater degree of deformation than the underlying ophiolite during both phases of deformation. The Nevadan deformation is expressed in the Galice Formation by rare SEE-trending isoclinal folds in bedding, and an east-dipping slaty cleavage which is parallel to bedding. The ophiolite was inhomogeneously flattened with generally little evidence of a deformation fabric. The post-Nevadan deformation is expressed in the Galice by kink, chevron, and concentric folding of bedding and cleavage, and by broad open folds in the ophiolite.

The age of the first deformation phase is well constrained by structural, stratigraphic and geochronological data, and is clearly related to the Nevadan orogeny. The Nevadan orogeny is a long recognized Late Jurassic deformational-metamorphic event that affected rocks as young as Kimmeridgian in northern California and southwestern Oregon [Blackwelder, 1914; Hinds, 1934; Taliaferro, 1942; Dott, 1966; Lanphere et al., 1968; Bateman and Clark, 1974]. Nevadan metamorphic ages of about $150 \mathrm{~m} . \mathrm{y}$. have been reported for Galice metagreywackes from the southern Klamath Mountains [Lanphere et al., 1978]. The $150 \mathrm{~m} . \mathrm{y}$. zircon age (sample PP582) on the deformed quartz keratophyre intrusion in the Galice volcaniclastic interval in conjunction with the metamorphic ages suggests that the Nevadan orogeny had commenced by the later stages of Galice deposition.

The age of the post-Nevadan deformation is less certain. If this folding event took place during thrusting of the Josephine section over the Franciscan Complex, then it is probably early Cretaceous in age. The folding probably also postdates the emplacement of the lower Coon Mountain 
intrusive complex (Figure 2) of which one phase is dated by zircon at 142 m.y. (sample J84Z, Table 1). Other possible isotopic constraints are the resetting of some $\mathrm{K} / \mathrm{Ar}$ systems in Late Jurassic intrusive rocks to early Cretaceous ages (sample D26, Table 2; Dick [1973, 1976]; and Snoke et al. [1981]). Such resetting may approximate cooling due to uplift during the second folding event. Furthermore, lower Cretaceous strata of the Horsetown Formation which uncomformably overlie the Galice Formation northeast of the study area have been tilted eastward [Wells et al., 1949], presumably as a result of post-Nevadan folding. These strata are Hauterivian in age (D. L. Jones, personal communication, 1979), or about 125 to 130 m.y. [Armstrong, 1978].

Nevadan deformation in the Preston Peak ophiolite is marked by its basal thrust fault. Along the thrust serpentinized peridotite and amphibolite tectonite of the lower basement complex, and cross-cutting dikes related to the upper mafic complex have together been disrupted into a zone of melange [Snoke, 1977]. The melange consists primarily of mafic blocks within a schistose serpentinite matrix. Melange development is clearly superimposed over the long history of tectonite development, metamorphism and subsequent mafic magmatism which together produced the polygenetic ophiolite. Significant high angle faults within the upper ophiolitic plate were originally interpreted as Nevadan age reverse faults [Snoke, 1977]. These upper plate structures include the Twin Peaks, Wounded Knee, and Broken Rib faults (Figure 2) which disrupt the ophiolite and separate it from stratified rocks of the western Paleozoic and Triassic belt. The Twin Peaks and smaller parallel faults are cut by the Bear Mountain intrusive complex (Figure 2). The 153 m.y. zircon age (sample PP572B) on a major phase of the complex indicates that these and perhaps other upper plate faults are pre-Nevadan. These data also suggest that the Bear Mountain complex is rootless above the thrust. The upper plate high-angle faults may thus have been related to ophiolite formation with normal and/or strike-slip displacements.

Ultramafic tectonites of both the Preston Peak and Josephine ophiolites exhibit penetrative structures which are distinct from Nevadan structures. Tectonite fabrics in ultramafic and associated mafic tectonites of the Preston Peak section reflect intense pre-mid Jurassic deformation and metamorphism typical of ophiolitic basement rocks of the western Paleozoic and Triassic belt and western Sierra Nevada region [Ando, 1977; Hotz et al., 1977; Medaris et al., 1980; Hanks, 1981; Saleeby, 1981, 1982]. Such deformation includes both upper mantle-lower crustal flow during ophiolite generation, and polyphase ophiolite distruption under a wide range of metamorphic conditions. As discussed earlier, high-temperature fabrics in the Josephine peridotite are considered to be of upper mantle origin [Himmelberg and Loney, 1973; Dick, 1977; Dick and Sinton, 1979]. Such mantle fabrics are presumably related to mantle dynamics during seafloor spreading generation of the Josephine ophiolite.

\section{Peridotitic to Dioritic Intrusive Complexes}

The Josephine and Preston Peak sections are cut by local representatives of a regional family of Jurassic intrusive complexes which range in composition from primarily peridotite to diorite. This belt extends from the southern Sierra Nevada northward through the Klamath Mountains [Snoke et al., 1982]. The local representatives include the Bear Mountain complex which cuts the Preston Peak ophiolite and adjacent strata of the western Paleozoic and Triassic belt, and the Lower Coon Mountain complex which cuts the Galice Formation.

The Bear Mountain intrusive complex covers an area of about $80 \mathrm{~km}^{2}$. Our studies have concentrated on its northern half (Figure 2). It consists of (1) satellitic masses of clinopyroxene-rich ultramafic and gabbroic rocks with subordinate dunite and hornblende-plagioclase pegmatoid, (2) two-pyroxene-biotite diorite and monzodiorite, (3) heterogeneous hornblende-rich rocks varying from gabbro to diorite, and (4) small granitoid masses consisting of biotite-bearing tonalite and granodiorite [Snoke et al., 1981]. Also associated with the complex are highly variable mafic to felsic dikes which cut primarily the country rocks. Some dikes are very similar in appearance to the $150 \mathrm{~m} . \mathrm{y}$. dikes in the Josephine-Galice section. As shown in Figure 2 the main mass of the Bear Mountain pluton is composite consisting primarily of the two-pyroxene dioritic phase and the hornblende dioritic phase. Concordant $\mathrm{Pb} / \mathrm{U}$ zircon ages (sample PP572B, Table 1) on the two-pyroxene phase show it to be $153 \mathrm{~m} . \mathrm{y}$. This phase is intruded and contact metamorphosed by the hornblende-rich phase which yields concordant 149 m.y. $\mathrm{Pb} / \mathrm{U}$ zircon ages (sample PP567, Table 1). The ultramafic phases occur along the flanks of the large composite mass.

The Bear Mountain complex was emplaced into the Preston Peak country rock assemblage shortly before or during the Nevadan orogeny. Mafic, ultramafic, and pelitic country rocks show a relatively narrow zone of dynamothermal metamorphism under hornblende hornfels and locally pyroxene hornfels facies conditions [Snoke et al., 1981]. Magmatic emplacement was chiefly by the forcible shouldering aside of country rock, although upper plate high-angle faults appear to have been instrumental in localizing the intrusion and perhaps giving it an elongate shape.

The lower Coon Mountain intrusive complex is a sill-like composite body that was preferentially emplaced along cleavage and bedding planes within the Galice Formation [Harper, 1980a]. The intrusion covers about $11 \mathrm{~km}^{2}$ and occupies the hinge area of a large syncline (Figure 2). Its roof is preserved along its southern margin where it dips beneath a thin cover of Galice Formation. The Galice Formation is converted to a biotite hornfels along the intrusive contact. The thickness of the intrusion ranges from 250 to $300 \mathrm{~m}$.

More than $90 \%$ of the lower Coon Mountain complex consists of ultarmafic rock, predominately olivine clinopyroxenite. Mafic to granitic rocks occur in a complex marginal facies, and as dikes that cut the main ultramafic body. A granodioritic mass from the marginal facies has yielded a 142 m.y. concordant zircon age (sample J84Z, Table 1). This represents a minimum age for the main ultramafic body inasmuch as the granodioritic material intrudes the ultramafic rocks and contains numerous ultramafic xenoliths. However, Harper [1980a] suggests that the 142 m.y. zircon age approximates the age of the entire complex since a complete range of compositions exists between ultramafic and granitic members and since the granitoid masses are spatially restricted to the complex. An additional age constraint is that it apparently postdates the Nevadan cleavage in the Galice Formation. Thus the lower Coon Mountain complex was emplaced between 150 and 142 m.y.

The lower Coon Mountain and Bear Mountain intrusive 
complexes belong to a regional family of Jurassic plutons which are characterized by clinopyroxene-rich ultramafic phases and a wide spectrum of more felsic phases which range through diorite and include various granitoids. Most plutons of the belt have wide ranges in silica content of between 40 and 70 weight percent with overall calc-alkaline trends [Snoke et al., 1982]. This calc-alkaline belt is distinct from major calc-alkaline plutonic belts such as the Cretaceous Sierra Nevada and Penninsula Range batholiths of California in that clinopyroxene-rich ultramafic and gabbroic rocks are ubiquitous, and the ultramafic to dioritic phases greatly predominate in volume over the granitoids. The peridotitic to dioritic intrusive complexes are in general restricted to zones with only ensimatic country rock and are roughly co-extensive and coeval with sequences of conspicuously clinopyroxene-phyric mafic to intermediate volcaniclastic rock. Such volcanic rocks occur in the Rogue Formation and are common in the Hayfork terrane of the western Jurassic and western Paleozoic and Triassic belts, respectively. It has been suggested that the peridotite to diorite plutons and clinopyroxene phyric volcaniclastic sequences are different manifestations of a complex ensimatic volcanoplutonic arc that was characterized by intense internal fracturing and rifting [Sharp and Wright, 1981; Saleeby, 1982; Snoke et al., 1982]. An example of such an arc terrane is the intensely fractured and rifted Solomon Islands where conspicuous clinopyroxene-phyric volcaniclastic and picritic flows constitute a significant proportion of the young volcanic centers, and very young two-pyroxene dioritic intrusives are exposed as well as metamorphosed mafic and ultramafic basement rock [Stanton and Bell, 1969; Coleman, 1970; Hackman, 1973]. In the final section below we will discuss the evolution of the Josephine and Preston Peak ophiolites and how they may relate to such a complex arc setting.

\section{Ophiolite Accretion in the West Central Klamath Mountains}

In the analysis of accretionary tectonics of the Klamath province attention has been focused on the imbrication of eugeosynclinal terranes and the development of an accretionary wedge-type orogen [Hamilton, 1969; Irwin, 1973]. It is thought that progressively younger exotic terranes were swept into the growing wedge through time by prolonged plate convergence. By this reasoning, if the western Klamath terranes alone are considered then about $100 \mathrm{~m} . \mathrm{y}$. of convergence transpired between the time that the western Paleozoic and Triassic belt began to accrete [Hotz et al., 1977; Davis et al., 1978], and the time that the Franciscan Complex was thrust beneath the western edge of the Klamath province [Irwin, 1981]. Recognizing that in the circumPacific realm $10 \mathrm{~m} . \mathrm{y}$. is a significant increment of time with respect to changes in plate-juncture patterns [Atwater, 1970; Karig, 1971; Hilde et al., 1977], the age and structural stratigraphic relations discussed above lead us to a somewhat different interpretation. Central to this issue is the concept of ophiolite accretion which has been limited to the imbrication or obduction of exotic ophiolite sheets during the compressional phases of orogeny. This concept as widely used is incomplete for it ignores the igneous accretion of juvenile oceanic crust by seafloor spreading during rifting and marginal basin formation within the orogen-a first order process in circum-Pacific tectonics. The imbrication process of ophiolite accretion is readily recognized by the mapping of thrust related structures, whereas rift-accretion features are not easily recognized for they must be read through the overprinted thrust structures from information within the stratigraphic records. Furthermore, the edges of rift basins are by nature prone to superimposed deformations by convergence and transform motions. Thus rift edge-zones are not readily preserved in a long-lived orogen.

In this article we have reviewed published data and presented new age data which record the processes of ophiolite accretion by a serial arrangement in time of compressional and extensional orogenic regimes. The Preston Peak ophiolite contains within its lower tectonite section the record of pre-mid Jurassic ophiolite disruption, metamorphism and presumably convergence-related accretion. Throughout the Klamath Mountains and western Sierra Nevada the signature of such an early Mesozoic compressive phase has been obscured by late-Jurassic Nevadan overprints [Davis et al., 1978; Saleeby, 1981, 1982]. However, within the stratigraphic record there is clear evidence that the pre-Nevadan and Nevadan compressive phases are distinct from one another and were separated in time by a major rifting phase [Saleeby, 1981, 1982; Sharp, 1980]. The Josephine ophiolite is considered an important expression of this rifting phase.

The critical time-stratigraphic relations within and between the Josephine and Preston Peak terranes are summarized in Table 3 . The spatial relations between the roughly coeval Josephine and Preston Peak ophiolites during their igneous formation is of great importance. The contact relations between the Josephine ophiolite and the Galice Formation, and the Galice sediment source data strongly suggest that the Josephine ophiolite formed in general proximity to the western Paleozoic and Triassic belt which includes the Preston Peak ophiolite. Such proximity is also suggested by the relatively short time interval between Josephine ophiolite formation and subsequent imbrication with the Preston Peak upper plate, and by a distinct pulse of intermediate arctype magmatism within both plates immediately prior to imbrication. Thus the two ophiolites, which are of distinctly different character, were constructed within proximity to one another at nearly the same point in time, and they subsequently experienced a similar structural and petrologic history.

The events which led to the formation and subsequent imbrication of the Josephine and Preston Peak ophiolites are shown diagrammatically in Figure 4 (modified after Snoke [1977] and Harper [1980a, b]). At about $157 \mathrm{m.y}$. the Josephine interarc basin opened by rifting and seafloor spreading. Inboard of the juvenile crust lies a remnant arc terrane similar to those described in the modern western Pacific by Karig [1972]. The remnant arc is constructed on tectonically accreted ophiolitic, chert-argillite and pre-late Jurassic volcanic arc fragments (western Paleozoic and Triassic belt). The subdued volcanic center shown in Figure $4 a$ is a hypothetical constructional center whose active life waned during the rifting event. Direct vestiges of this center may be represented by the Rogue Formation, whereas indirect plutonic vestiges are likely to be the 170 to $160 \mathrm{~m}$.y. plutons that are widespread in the western Paleozoic and Triassic belt (Figure 1) [Allen et al., 1982; Snoke et al., 1982]. The Preston Peak ophiolite is thought to have formed along the inner edge of the remnant arc as an edge-zone 
complex. Pre-Nevadan high-angle faults in the ophiolite may represent rift-edge structures.

The nature of the break between the Josephine basin floor and the remnant arc is an important consideration. Was it a normal or transform rift edge? Interarc and marginal basins such as the Andaman Sea, Gulf of California and those of the Solomon Islands have major transform-type junctures along basin edges [Hackman, 1973; Lawver and Hawkins, 1978; Curray et al., 1979]. Such dynamics are typical of zones with oblique plate interactions. The tremendous latitudinal shifts proposed for Mesozoic time along western North America [Packer and Stone, 1974; Hillhouse, 1977; Jones et al., 1977,
1978; Van der Voo et al., 1980] certainly make transform basin edges as likely a possibility as edges with predominately normal faults. Furthermore, restored sheeted dike orientations in the Josephine ophiolite trend at high angles to the Preston Peak fault which in the simplest interpretation suggests original transform motion between the Josephine basin and the remnant arc terrane.

Deposition of the Galice submarine fan is shown in Figure 4b. The volcanic-rich detritus which lies above the thin hemipelagic sequence was presumably derived from the waning volcanic center of the remnant arc terrane. The main detrital influx for the Galice fan was derived from basement

TABLE 3. Summary of stratigraphic and structural relations within and between Josephine and Preston Peak terranes*

Time

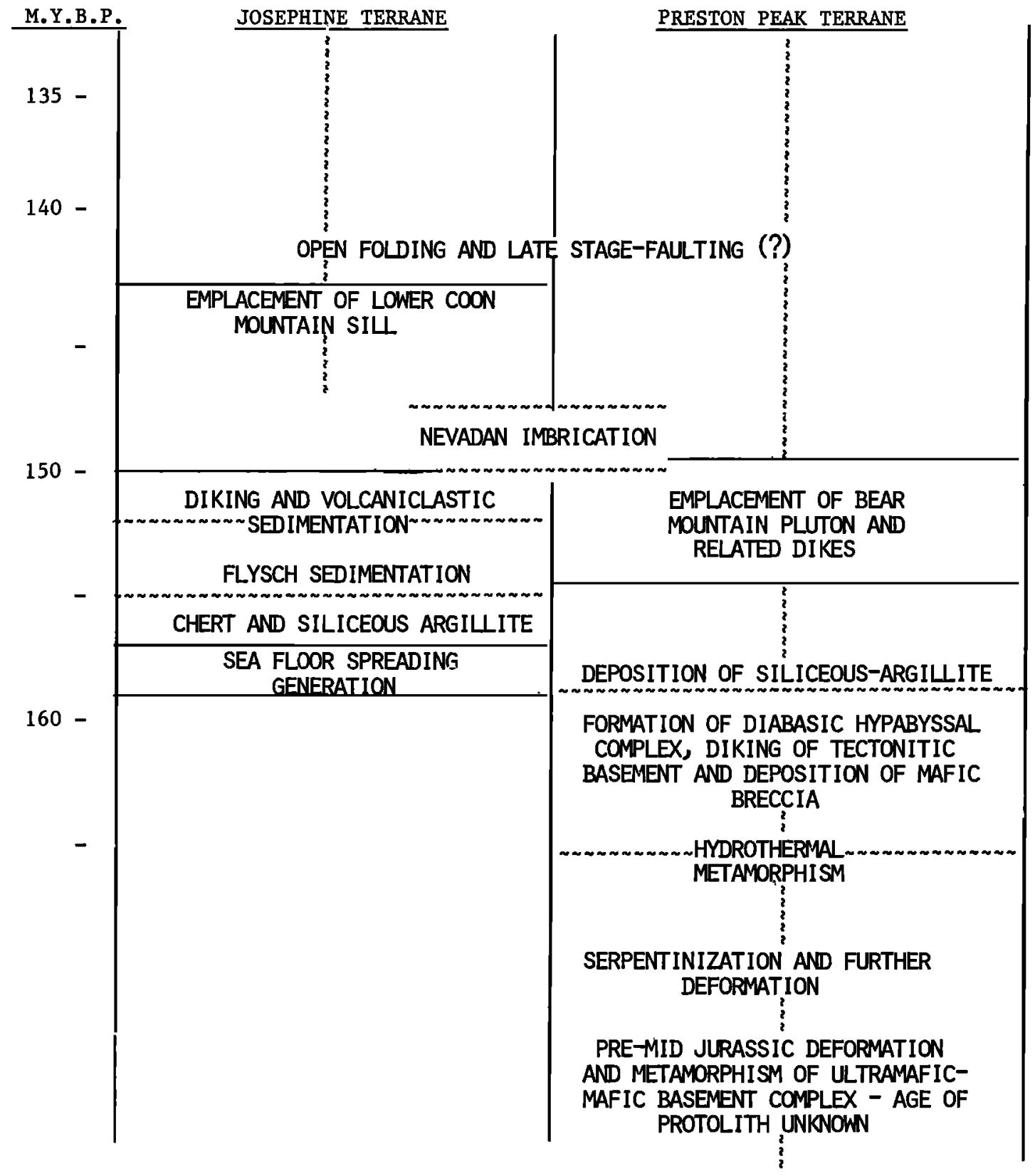

* solid lines denote well-constrained time boundaries, broken wavy 1ines are approximate boundaries, vertical wavy lines denote processes not highly constrained in time. 


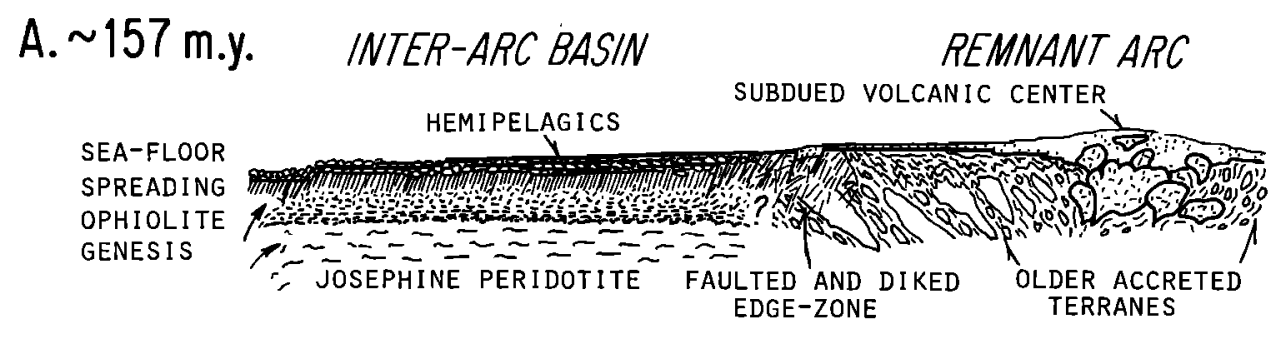

B. $155-150$ m.y.
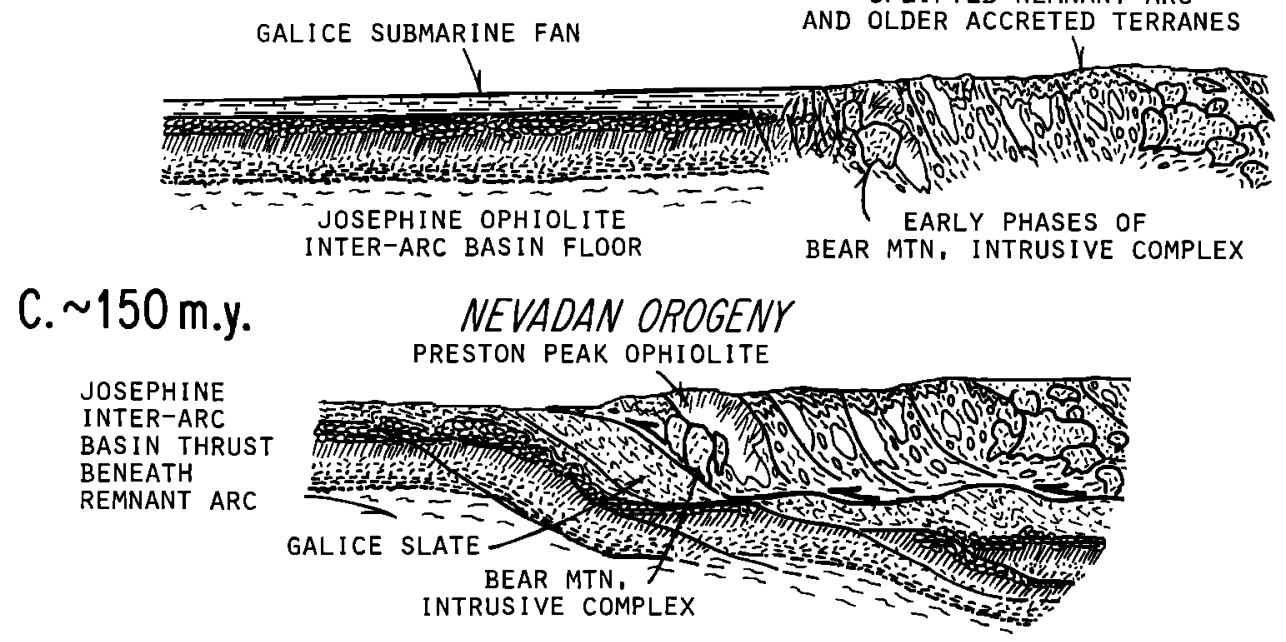

Fig. 4. Diagrammatic sketches showing general role of Josephine and Preston Peak sections during (a) rifting generation of Josephine interarc basin, $(b)$ deposition of the Galice Formation, and $(c)$ Nevadan orogeny closure of basin (modified from Snoke [1977], Harper [1980a, b]).

assemblages of the remnant arc. These rocks are shown as emergent in Figure $4 b$. Craton-derived admixtures to the detritus could either have been derived directly from older Paleozoic terranes to the east or reworked from early Mesozoic clastic rocks within the remnant arc basement. Local volcaniclastic intervals within the Galice fan sequence suggest that arc volcanism was re-established within or along the margins of the interarc basin following its formation. This is further supported by the intermediate-composition dikes and sills which cut the Galice-Josephine section and by the coeval Bear Mountain intrusive complex and similar dikes which cut the Preston Peak section. The re-establishment of arc activity within and along the interarc basin edge is suggestive of a complex basin geometry. Such a complex geometry is reminiscent of the Solomons and Sunda arcs where there are significant transform structures in conjunction with oblique rift basins.

Uplift of the remnant arc terrane and the shedding of the Galice fan detritus may represent the first stages of the Nevadan orogeny. The outstanding expression of the Nevadan orogeny in the study area is the slaty cleavage in the Galice Formation and the Preston Peak thrust fault (Figure 2). The cleavage formation presumably represents the metamorphic peak for the orogeny, which has been dated to the south at about $150 \mathrm{~m} . \mathrm{y}$. [Lanphere et al., 1978]. Whether the Preston Peak thrust accompanied the metamorphic peak in the study area is unclear. If so, there is an apparent space problem, for the distinct arc-type igneous pulse manifest in late-stage dikes, sills, and volcaniclastic rocks of the Josephine-Galice section, and the Bear Mountain intrusive complex of the upper plate, would essentially have been coeval with thrusting. Nevertheless, the thrust geometry is consistent with the cleavage and fold geometry in the Galice slate (Figure 2) and is shown dramatically as such in Figure $4 c$.

The sequence of events depicted in Figure 4 present our general view of the Nevadan orogeny. Shortly after the Josephine ophiolite formed by a short-lived spreading event, the resulting interarc basin closed by convergence beneath the remnant arc. Convergence on the order of $100 \mathrm{~km}$ or more is suggested by the presence of Galice-type rocks in the Condrey Mountain window exposed east of the study area (Figure 1; Klein [1977]). The geochronological and stratigraphic data constrain the transition from spreading to convergent tectonics to within 10 and perhaps $5 \mathrm{~m}$.y. Such tight constraints are not readily available in the ancient geological record and are not unlike rates of rapid changes along modern continental margin plate junctures. The question concerning the precise timing of the Preston Peak thrust may be irresolvable considering that deposition of the Galice volcaniclastic interval and emplacement of the quartz keratophyre sill and then advancement of the upper thrust plate and cleavage development could at modern rates be contained within the analytical uncertainty of the zircon age data. We feel that this is the solution to the space problem. This problem is compounded because the age data on the Galice metamorphism is by $\mathrm{K} / \mathrm{Ar}$ techniques and are from rocks located to the south of the study area. Thus the uncertainty in matching of the two sets of geochronological data is also of critical size with respect to the processes we wish to characterize in time.

Additional remnants of the pre-Nevadan rifting event may include the western Sierra Nevada Smartville ophiolite, the 
California Coast Range ophiolite [Saleeby, 1981], and a regional tholeiitic dike swarm which cuts Paleozoic and early Mesozoic metamorphic units and Lower and Middle Jurassic volcano-plutonic arc rocks of the western and northern
Sierra Nevada [Sharp, 1980]. As in the Klamath Mountains region these apparent interarc rift assemblages were involved in a Nevadan (or Nevadan age) metamorphic-deformational pulse shortly after their igneous formation.

TABLE 4. Geochronological Sample Location, Petrography, and Zircon Yield Data

\begin{tabular}{|c|c|c|c|}
\hline $\begin{array}{l}\text { Sample } \\
\text { Number }\end{array}$ & $\begin{array}{l}\text { Field Setting } \\
\text { and Location }\end{array}$ & Petrography and Special Comments & $\frac{\text { mg Zircon }}{\text { kg Rock }}$ \\
\hline PP322 & $\begin{array}{l}\text { Dike within mafic complex on } \\
\text { Preston Peak. Lat. } \\
41^{\circ} 50^{\prime} 04^{\prime \prime} \mathrm{N} \text {, long. } \\
123^{\circ} 36^{\prime} 40^{\prime \prime} \mathrm{W} \text {. Preston Peak } \\
15^{\prime} \text { quad. }\end{array}$ & $\begin{array}{l}\text { Statically metamorphosed biotite quartz diorite: Strongly zoned subtabular } \\
\text { plagioclase (andesine to oligoclase), interstitial quartz, ragged biotite, and } \\
\text { opaque minerals. Minor accessories include sphene, apatite, and zircon. } \\
\text { No potash feldspar seen. Saussuritic alteration of plagioclase cores is com- } \\
\text { mon; biotite aggregates are commonly partially altered to chlorite and } \\
\text { white mica. }\end{array}$ & $12 / 123$ \\
\hline A45Z & $\begin{array}{l}\text { Large slide boulder on Smith } \\
\text { River, derived from slump in }\end{array}$ & $\begin{array}{l}\text { Fine-grained plagiogranite: Albitized plagioclase, quartz, magnetite, apa- } \\
\text { tite. Euhedral plagioclase and interstitial myrmekitic plagioclase + quartz. }\end{array}$ & $41 / 192$ \\
\hline
\end{tabular}
high-level intrusives. Lat. $41^{\circ} 49^{\prime} 18^{\prime \prime} \mathrm{N}$, long.

$124^{\circ} 01^{\prime} 47^{\prime \prime} \mathrm{W}$. Hiouchi 7-1/2' quad.

A88Z Sheeted dikes on Smith River, $0.5 \mathrm{mi}$ W of mouth of Hardscrabble Creek. Lat. $41^{\circ} 50^{\prime} 16^{\prime \prime} \mathrm{N}$, long. $124^{\circ} 02^{\prime} 05^{\prime \prime} \mathrm{W}$. Hiouchi 7-1/2' quad.

C23 Cross-cutting dike on Hurdygurdy Creek, approx. 0.35 mi NE of Horse Flat. Lat. $41^{\circ} 44^{\prime} 20^{\prime \prime} \mathrm{N}$, long. $123^{\circ} 52^{\prime} 50^{\prime \prime}$. Ship Mountain $15^{\prime}$ quad.

PP572B Massive plutonic rock from logging roadcut. Lat. $41^{\circ} 47^{\prime} 59^{\prime} \mathrm{N}$, long. $123^{\circ} 43^{\prime} 27^{\prime \prime}$ W. Preston Peak $15^{\prime}$ quad.

PP567 Massive plutonic rock exposed in hilly area. Lat. $41^{\circ} 49^{\prime} 03^{\prime \prime} \mathrm{N}$, long. $123^{\circ} 41^{\prime} 18^{\prime \prime}$ W. Preston Peak $15^{\prime}$ quad.

PP582

Shattered sill-like body in logging road cut. Lat. $41^{\circ} 54^{\prime} 45^{\prime \prime} \mathrm{N}$, long. $123^{\circ} 40^{\prime} 52^{\prime \prime} \mathrm{W}$. Preston Peak $15^{\prime}$ quad.

J84Z Intrudes ultramafic rock of Lower Coon Mtn. pluton, along road cut on logging road. Lat. $41^{\circ} 45^{\prime} 04^{\prime \prime} \mathrm{N}$, long. $123^{\circ} 56^{\prime} 29^{\prime \prime} \mathrm{W}$. Gasquet $15^{\prime}$ quad.

PP580 Monolithologic block in ultramafic matrix. Lat. $41^{\circ} 54^{\prime} 59^{\prime \prime} \mathrm{N}$, long. $123^{\circ} 40^{\prime} 13^{\prime \prime}$ W. Preston Peak 15 ' quad.

K20 Dike within swarm which intrudes Josephine peridotite on road cut $1.2 \mathrm{mi} \mathrm{S}$ of $\mathrm{Kel}$ ly Peak. Lat. $41^{\circ} 50^{\prime} 07^{\prime \prime} \mathrm{N}$, long. $123^{\circ} 50^{\prime} 41^{\prime \prime} \mathrm{W}$. Gasquet $15^{\prime}$ quad.

D26 Sill within Galice Formation on Middle Fork of Smith River, approx. $600 \mathrm{ft} \mathrm{NE}$ of mouth of Little Jones Creek. tite. Euhedral plagioclase and interstitial myrmekitic plagioclase + quartz. Secondary epidote, chlorite, albite.

Plagiogranite: 0.5 - to $1-\mathrm{mm}$ euhedral turbid plagioclase in very fine groundmass of plagioclase, quartz, hornblende, magnetite, sphene. Secondary chlorite, vein prehnite.

Metadacite: Strongly foliated with relict phenocrysts of albitized feldspar and alanite? Secondary albite, quartz, muscovite, epidote, calcite.

Biotite-two-pyroxene monzodiorite: Subhedral tablets of plagioclase (commonly 4-5 mm long) locally surrounded by poikilitic alkali feldspar. Pyroxenes (augite $>$ hypersthene) are the chief mafic minerals with biotite occurring as poikilitic patches around pyroxene clots. Quartz is interstitial and commonly is associated with biotite as a late magmatic reaction product of hypersthene. Magnetite, ilmenite, zircon, and apatite accessories.

Biotite-hornblende quartz diorite: Tabular plagioclase and ophitic to subophitic mafic mineral clots, both which define a moderate foliation. Mafic clots consist of hornblende, lesser biotite and opaque oxides occur as late magmatic reaction products. Ubiquitous interstitial quartz. Some hornblende grains have bleached cores and contain small quartz inclusions suggesting the original presence of pyroxene. Accessory apatite, sphene, and zircon.

Porphyritic quartz keratophyre: Small phenocrysts of sodic plagioclase in allotriomorphic-granular mix of sodic plagioclase and quartz. Epidote, white mica, and chlorite ubiquitous, indicating pervasive postmagmatic hydrothermal alteration. Accessory magnetite, sphene, and apatite.

Granodiorite: Fine-grained allotriomorphic plagioclase $\left(\mathrm{An}_{18-40}\right)$, orthoclase, quartz, biotite, magnetite. Secondary chlorite. Erroneous age given by Harper and Saleeby [1980].

Amphibolite: Relict prograde metamorphic fabric defined by brown-green hornblende, plagioclase, and epidote overprinted by isotropic-textured green amphibole, clinozosite, and recrystallized plagioclase.

Meta-andesite: Large hornblende phenocrysts in groundmass of hornblende, and secondary chlorite, epidote, quartz, albite, muscovite.

hornblende separate

Meta-andesite: Large hornblende and lesser augite phenocrysts. Secondary hornblende chlorite, epidote, quartz, calcite, albite, and rare actinolite and prehnite. Orthopyroxene (?) pseudomorphs.

homblende separate

Lat. $41^{\circ} 52^{\prime} 17^{\prime \prime} \mathrm{N}$, long. $123^{\circ} 49^{\prime} 49^{\prime \prime} \mathrm{W}$. Gasquet $15^{\prime}$ quad. 
The deformation and metamorphism of oceanic basement followed by arc magmatism, rapid rifting and basin development, orogeny associated with basin closure, and then continued arc magmatism are a pattern similar to that of a complex arc terrane such as the Solomon Islands [Hackman, 1973; Karig, 1972]. The Solomon arc consists of en echlon remnant arc segments and major transcurrent fault zones related to oblique convergence, unevenly spaced volcanic constructional centers, metamorphosed oceanic basement uplifts, and partially closed interarc basins. On the basis of petrological similarities in arc-type volcanic and plutonic assemblages Snoke et al. [1982] and Saleeby [1982] drew an analogy between the Mesozoic Klamath-western Sierra region and the modern Solomon arc. The ophiolitic tectonics discussed here and their tight time relationships with the products of arc-magmatism are consistent with such an analogy.

An additional point of importance which has not been discussed is the concept of arc polarity. Inasmuch as the Solomon arc has apparently reversed its polarity in the recent geologic past [Karig, 1972] we should consider the implications of such a phenomenon on the Nevadan event. It is important to note that a consistent linear volcano-plutonic locus was not maintained during Jurassic time in the Klamath province [Lanphere et al., 1968; 5 Charlton, 1977; Davis et al., 1978; Wright, 1980; Snoke et al., 1982]. Thick, apparently short-lived volcanic piles and composite plutonic centers formed over a very broad area without well-defined time-space patterns. It is thus impossible to define arc polarity based on temporal or compositional patterns in space. Nevertheless, the structural framework of the Klamath province and the general age progression in accreted terranes seemingly indicate a west-facing arc system with eastward subduction of oceanic assemblages beneath the province. Such polarity does not negate a collisional-type of orogeny within the orogen in the event of an arc-reversal following rifting. A collisional origin for the Nevadan orogeny has been suggested by Moores [1970] and Schweickert and Cowan [1975]. The point we emphasize here is that such an orogeny should be considered to have occurred within the orogen, which in this case should limit the concept of exotic terranes. For example different thrust plates may be allochthonous or exotic to one another, but not necessarily exotic to the orogenic zone.

In the case of the Nevadan orogeny in the west central Klamath province, there is no evidence for an arc-reversal or a change in overall polarity. The pattern appears to have been convergence and conceivably subduction of young interarc basin floor beneath the adjacent remnant arc with preservation of the existing polarity. Whether the convergence was established along a normal versus transform basin edge is unclear. In Figure 4 we have not accounted for possible strike-slip motion within the system, a problem that is probably widespread along the entire western cordillera.

Acknowledgments. Conversations and written communications with W. P. Irwin and D. L. Jones were of great assistance for this study, and critical reviews by R. G. Coleman and J. E. Wright were helpful. Support from NSF grant EAR 7925998 is gratefully acknowledged by J. B. Saleeby. A. W. Snoke gratefully acknowledges a faculty research grant from the University of South Carolina that partially supported field expenses during this study. We would also like to thank C. D. Ando, J. E. Quick, and C. J. SunRidge-Saleeby for helping us pack out the large zircon sample from Preston Peak.
C. J. SunRidge-Saleeby is also acknowledged for patience and expertise in final hand purification of zircon separates. Contribution 3618 of the Division of Geological and Planetary Sciences, California Institute of Technology, Pasadena, California.

\section{REFERENCES}

Allen, C. M., C. G. Barnes, M. A. Kays, and J. B. Saleeby, Comagmatic nature of the Wooley Creek batholith and the Slinkard pluton and age constraints on tectonic and metamorphic events in the western Paleozoic and Triassic belt, Klamath Mountains, N. California, Geol. Soc. Am. Abstr. Programs, 14, in press, 1982.

Ando, C. D., Disrupted ophiolite sequence in the south-central Klamath Mountains, California, Geol. Soc. Am. Abstr. Programs, 9, 380, 1977.

Ando, C. D., W. P. Irwin, D. L. Jones, and J. B. Saleeby, The ophiolitic North Fork Terrane in the Salmon River region, central Klamath Mountains, California, Geol. Soc. Am. Bull., in press, 1982.

Armstrong, R. L., Pre-Cenozoic Phanerozoic time scale-Computer file of critical dates and consequences of new and in-progress decay-constant revisions, Am. Assoc. Pet. Geol. Stud. Geol., 6, 73-91, 1978.

Atwater, T., Implications of plate tectonics for the Cenozoic tectonic evolution of western North America, Geol. Soc. Am. Bull., 81, 3513-3536, 1970.

Bailey, E. H., M. C. Blake, and D. L. Jones, On-land Mesozoic oceanic crust in California Coast Ranges, U.S. Geol. Surv. Prof. Pap., 700-C, 70-81, 1970.

Bateman, P. C., and L. D. Clark, Stratigraphic and structural setting of the Sierra Nevada batholith, Pac, Geol., 8, 78-89, 1974.

Blackwelder, E., A summary of the orogenic epochs in the geologic history of North America, J. Geol., 22, 633-654, 1914.

Bond, G. C., and J. C. DeVay, Petrology and provenance of a preUpper Devonian quartzose flysch in the northern Sierra Nevada, California: Implications to the tectonic history of the Sierra Nevada Block, Geol. Soc. Am. Abstr. Programs, 11, 70-71, 1979.

Cater, F. W., Jr., and F. G. Wells, Geology and mineral resources of the Gasquet Quadrangle, California-Oregon, U.S. Geol. Surv. Bull., 995-C, 79-133, 1953.

Charlton, D., Preliminary report on the petrology of the Ironside Mountain batholith, Klamath Mountains, northern California, Geol. Soc. Am. Abstr. Programs, 9, 399, 1977.

Coleman, P. J., Geology of the Solomon and New Hebrides Islands, as part of the Melanesian Re-entrant, Southwest Pacific, Pac. Sci., 24, 289-314, 1970.

Coleman, R. G., Ophiolites: Ancient Oceanic Lithosphere?, 229 pp., Springer, New York, 1977.

Curray, J. R., D. G. Moore, L. A. Lawver, R. W. Raitt, and M. Henry, Tectonics of the Andaman Sea and Burma, in Geological and Geophysical Investigations of Continental Margins, Mem. 29, edited by J. S. Watkins et al., pp. 189-198, American Association of Petroleum Geologists, Tulsa, Okla., 1979.

Dalrymple, G. B., and M. A. Lanphere, Potassium-Argon Dating, 258 pp., W. H. Freeman, San Francisco, Calif., 1969.

Dalziel, I. W., M. J. de Wit, and K. F. Palmer, Fossil marginal basin in the southern Andes, Nature, 250, 291-294, 1974.

Davis, G. A., Westward thrust faulting in the south-central Klamath Mountains, California, Geol. Soc. Am. Bull., 79, 911-934, 1968.

Davis, G. A., J. W. H. Monger, and B. C. Burchfiel, Mesozoic construction of the Cordilleran 'collage,' central British Columbia to central California, in Mesozoic Paleogeography of the Western United States, Paleogeogr. Symp. 2, edited by D. G. Howell and K. A. McDougall, pp. 1-32, Pacific Section, Society of Economic Paleontologists and Mineralogists, Los Angeles, Calif., 1978.

Dick, H. J. B., K-Ar dating of intrusive rocks in the Josephine peridotite and Rogue Formation west of Cave Junction, southwestern Oregon, Geol. Soc. Am. Abstr. Programs, 5, 33-34, 1973.

Dick, H. J. B., The origin and emplacement of the Josephine peridotite of southwestern Oregon, Ph.D. thesis, 409 pp., Yale Univ., New Haven, Conn., 1976.

Dick H. J. B., Partial melting in the Josephine peridotite, I, The effect on mineral composition and its consequences for geobarometry and geothermometry, Am. J. Sci., 277, 801-832, 1977.

Dick, H. J. B., and J. M. Sinton, Compositional layering in alpine 
peridotites: Evidence for pressure solution creep in the mantle, $J$. Geol., 87, 403-416, 1979.

Dott, R. H., Jr., Late Jurassic unconformity exposed in southwestem Oregon: Oregon Department of Geology and Mineral Industries, Ore Bin, 28, 85-97, 1966.

Evarts, R. C., The geology and petrology of the Del Puerto ophiolite, Diablo Range, central California Coast Ranges, in North American Ophiolites, Bull. 95, edited by R. G. Coleman and W. P. Irwin, pp. 121-139, Oregon Department of Geology and Mineral Industries, Portland, 1977.

Ewart, A., Mineralogy and chemistry of modern orogenic lavasSome statistics and implications, Earth Planet. Sci. Lett., 31, 417 $432,1976$.

Garcia, M. O., Petrology of the Rogue and Galice Formation, Klamath Mountains, Oregon: Identification of a Jurassic island arc sequence, J. Geol., 86, 29-41, 1979.

Hackman, B. D., The Solomon Islands fractured arc, in The Western Pacific, Island Arcs, Marginal Basins, Geochemistry, edited by P. J. Coleman, pp. 179-191, University of Australia Press, Canberra, 1973.

Hamilton, W., Mesozoic California and the underflow of Pacific mantle, Geol. Soc. Am. Bull., 80, 2409-2430, 1969.

Hanks, C. L., Thrusting of the western Triassic and Paleozoic belt in the north-central Klamath Mountains, and the relationship of the Tom Martin ultramafic complex and adjacent metamorphic rocks, Geol. Soc. Am. Abstr. Programs, 13, 58, 1981.

Harper, G. D., Structure and petrology of the Josephine ophiolite and overlying metasedimentary rocks, northwestern California, Ph.D. thesis, 259 pp., Univ. of Calif., Berkeley, 1980a.

Harper, G. D., The Josephine ophiolite-Remains of a late Jurassic marginal basin in northwestern California, Geology, 8, 333-337, $1980 b$.

Harper, G. D., and J. B. Saleeby, Zircon ages of the Josephine ophiolite and the Lower Coon Mountain pluton, western Jurassic belt, NW California, Geol. Soc. Am. Abstr. Programs, 12, 109$110,1980$.

Hilde, T. W. C., S. Uyeda, and L. Kroenke, Evolution of the western Pacific and its margin, Tectonophysics, 38, 145-165, 1977.

Hillhouse, J., Paleomagnetism of the Triassic Nikolai greenstone, south-central Alaska, Can. J. Earth Sci., 14, 2578-2592, 1977.

Himmelberg, G. R., and R. A. Loney, Petrology of the Vulcan Peak alpine-type peridotite, southwestern Oregon, Geol. Soc. Am. Bull., 84, 1585-1600, 1973.

Hinds, N. E. A., The Jurassic age of the last granitoid intrusives in the Klamath Mountains and Sierra Nevada, California, Am. J. Sci., 227, 182-192, 1934.

Hodges, F. N., Crystallization sequence as a key to ophiolite petrogenesis (abstract), Eos Trans. AGU, 57, 342, 1976.

Hotz, P. E., Plutonic rocks of the Klamath Mountains, California and Oregon, U.S. Geol. Surv. Prof. Pap., 684-B, 19 pp., 1971.

Hotz, P. E., M. A. Lanphere, and D. A. Swanson, Triassic blueschist from northern California and north-central Oregon, Geology, 5, 659-663, 1977.

Imlay, R. W., Succession and speciation of the pelecypod Aucella, U.S. Geol. Surv. Prof. Pap., 314-G, 155-169, 1959.

Ingersoll, R. V., Submarine fan facies of the Upper Cretaceous Great Valley Sequence, northern and central California, Sediment. Geol., 21, 205-230, 1978.

Irwin, W. P., Geologic reconnaissance of the northern Coast Ranges and Klamath Mountains, California, with a summary of the mineral resources, Bull. Calif. Div. Mines Geol., 179, 80 pp., 1960.

Irwin, W. P., Late Mesozoic orogenies in the ultarmafic belts of northwestern Oregon, U.S. Geol. Surv. Prof. Pap., 50I-C 1-9, 1964.

Irwin, W. P., Geology of the Klamath Mountains Province, Bull. Calif. Div. Mines Geol., 190, 19-38, 1966.

Irwin, W. P., Terranes of the western Paleozoic and Triassic belt in the southem Klamath Mountains, California, U.S. Geol. Surv. Prof. Pap., 800-C, 103-111, 1972.

Irwin, W. P., Sequential minimum ages of oceanic crust in accreted tectonic plates of northern California and southern Oregon, Geol. Soc. Am. Abstr. Programs, 5, 62-63, 1973.

Irwin, W. P., Ophiolitic terranes of California, Oregon, and Nevada, Oreg. Dep. Geol. Miner. Res. Bull., 95. 75-92, 1977.

Irwin, W. P., Tectonic accretion of the Klamath Mountains, in The
Geotectonic Development of California, Rubey Vol. I, edited by W. G. Ernst, pp. 29-49, Prentice-Hall, Englewood Cliffs, N. J., 1981.

Irwin, W. P., D. L. Jones, and E. A. Pessagno, Jr., Significance of Mesozoic radiolarians from the pre-Nevadan rocks of the southem Klamath Mountains, California, Geology, 5, 557-562, 1977.

Irwin, W. P., D. L. Jones, and T. A. Kaplan, Radiolarians from preNevadan rocks of the Klamath Mountains, California and Oregon, in Mesozoic Paleogeography of the Western United States, Paleogeogr. Symp. 2, edited by D. G. Howell and K. A. McDougall, pp. 303-310, Pacific Section, Society of Economic Paleontologists and Mineralogists, Los Angeles, Calif., 1978.

Jones, D. L., N. J. Silberling, and J. Hillhouse, Wrangellia-A displaced terrane in northwestern North America, Can.J. Earth Sci., 14, 2565-2577, 1977.

Jones, D. L., N. J. Silberling, and J. Hillhouse, Microplate tectonics of Alaska-Significance for the Mesozoic history of the Pacific coast of North America, in Mesozoic Paleogeography of the Western United States, Paleogeogr. Symp. 2, edited by D. G. Howell and K. A. McDougall, pp. 71-74, Pacific Section, Society of Economic Paleontologists and Mineralogists, Los Angeles, Calif., 1978.

Karig, D. E., Origin and development of marginal basins in the western Pacific, J. Geophys. Res., 76, 2542-2561, 1971.

Karig, D. E., Remnant arcs, Geol. Soc. Am. Bull., 83, 1057-1068, 1972.

Kidd, W. S. F., The Baie Verte Lineament, Newfoundland: Ophiolite complex floor and mafic volcanic fill of a small Ordovician marginal basin, in Island Arcs, Deep Sea Trenches, and Back-Arc Basins, edited by M. Talwani and W. C. Pitman III, pp. 407-418, AGU, Washington, D. C., 1977.

Klein, C. W., Thrust plates of the north-central Klamath Mountains near Happy Camp, California, Spec. Publ. Calif. Div. Mines Geol., 28, 23-26, 1977.

Krogh, T. E., A low-contamination method for hydrothermal decomposition of zircon and extraction of $\mathrm{U}$ and $\mathrm{Pb}$ for isotope age determination, Geochim. Cosmochim. Acta, 37, 485-494, 1973.

Lanphere, M. A., W. P. Irwin, and P. E. Hotz, Isotopic age of the Nevadan Orogeny and older plutonic and metamorphic events in the Klamath Mountains, California, Geol. Soc. Am. Bull., 79, 1027-1052, 1968.

Lanphere, M. A., M. C. Blake, Jr., and W. P. Irwin, Early Cretaceous metamorphic age of the South Fork Mountain Schist in the northern Coast Ranges of California, Am. J. Sci., 278, 798815, 1978.

Lawver, L. A., and J. W. Hawkins, Diffuse magnetic anomalies in marginal basins: Their possible tectonic and petrologic significance, Tectonophysics, 45, 323-339, 1978.

Medaris, L. G., Jr., and J. L. Welsh, Prograde metamorphism of serpentinite in the western Paleozoic and Triassic belt, Klamath Mountains Province, Geol. Soc. Am. Abstr. Programs, 12, 120, 1980.

Moores, E. M., Ultramafics and orogeny, with models of the U.S. Cordillera and the Tethys, Nature, 228, 837-842, 1970.

Mutti, E., and F. Ricci-Lucchi, Le torbiditi den' Appennino settentrionale: Introduzione all' analisis di facies, Soc. Geol. Ital. Mem., 11, 161-199, 1972. (Engl. transl. Int. Geol. Rev., 20, 125166, 1972.)

Packer, D. R., and D. B. Stone, Paleomagnetism of Jurassic rocks from southern Alaska and the tectonic implications, Can.J. Earth Sci., 11, 976-997, 1974.

Potter, A. W., P. E. Hotz, and D. M. Rohr, Stratigraphy and inferred tectonic framework of Lower Paleozoic rocks in the eastern Klamath Mountains, northern California, in Paleozoic Paleogeography of the Western United States, edited by J. H. Stewart, C. H. Stevens, and A. E. Fritsche, pp. 421-440, Pacific Section, Society of Economic Paleontologists and Mineralogists, Los Angeles, Calif., 1977.

Ramp, L., Geology and mineral resources of the Upper Chetco drainage area, Oregon, Oreg. Dep. Geol. Miner. Ind. Bull., 88, 47 pp., 1975.

Saleeby, J. B., Ocean floor accretion and volcano-plutonic are evolution of the Mesozoic Sierra Nevada, in The Geotectonic Development of California, Rubey Vol. I, edited by W. G. Ernst, pp. 132-181, Prentice-Hall, Englewood Cliffs, N. J., 1981.

Saleeby, J. B., Polygenetic ophiolite belt of the California Sierra Nevada-geochronological and tectonostratigraphic develop- 
ment, J. Geophys. Res., 87, 1803-1824, 1982.

Saleeby, J. B., and W. D. Sharp, Chronology of the structural and petrologic development of the southwest Sierra Nevada foothills, California, II, Geol. Soc. Am. Bull., 91, 1416-1535, 1980.

Schweickert, R. A., and D. S. Cowan, Early Mesozoic tectonic evolution of the western Sierra Nevada, California, Geol. Soc. Am. Bull., 86, 1329-1336, 1975.

Sharp, W. D., Ophiolite accretion in the northern Sierra (abstract), Eos Trans. $A G U, 61,1122,1982$.

Sharp, W. D., and J. E. Wright, Jurassic metavolcanic sequences in the western Sierra-Klamath Provinces: Character and tectonic significance, Geol. Soc. Am. Abstr. Programs, 13, 105, 1981.

Smewing, J. D., K. O. Simonian, and I. G. Gass, Metabasalts from the Troodos massif, Cyprus; genetic implications deduced from petrography and trace element geochemistry, Contrib. Mineral. Petrol., 51, 49-64, 1975.

Snoke, A. W., A thrust plate of ophiolitic rocks in the Preston Peak area, Klamath Mountains, California, Geol. Soc. Am. Bull., 88, 1641-1659, 1977.

Snoke, A. W., and L. C. Calk, Jackstraw-textured talc-olivine rocks, Preston Peak area, Klamath Mountains, California, Geol. Soc. Am. Bull., 89, 223-230, 1978.

Snoke, A. W., and S. E. Whitney, Relict pyroxenes from the Preston Peak ophiolite, Klamath Mountains, California, Am. Mineral., 64, 865-873, 1979.

Snoke, A. W., H. R. Bowman, and A. J. Hebert, The Preston Peak ophiolite, Klamath Mountains, California, an immature island arc: Petrochemical evidence, Spec. Rep. Calif. Div. Mines Geol., I29, 67-79, 1977.

Snoke, A. W., J. E. Quick, and H. R. Bowman, Bear Mountain igneous complex, Klamath Mountains, California: An ultrabasic to silicic calc-alkaline suite, J. Petrol., 22, 501-552, 1981.

Snoke, A. W., W. D. Sharp, J. E. Wright, and J. B. Saleeby, Petrotectonic significance of mid-Mesozoic peridotitic to dioritic intrusive complexes, Klamath Mountains, California, Geology, 10, 160-166, 1982.

Stanton, R. L., and J. D. Bell, Volcanic and associated rocks of the New Georgia Group, British Solomon Islands Protectorate, Overseas Geol. Miner. Res., 10, 113-145, 1969.

Taliaferro, N. L., Geologic history and correlation of the Jurassic of southwestern Oregon and California, Geol. Soc. Am. Bull., 53, 71-112, 1942.
Upadhyay, H. D., and E. R. W. Neale, On the tectonic regimes of ophiolite genesis, Earth Planet. Sci. Lett., 43, 93-102, 1979.

Vail, S. G., Geology and geochemistry of the Oregon Mountain area, southwestern Oregon and northern California, Ph.D. thesis, 159 pp., Oreg. State Univ., Corvallis, 1977.

Van der Voo, R., M. Jones, D. S. Gromme, G. D. Eberlein, and M. Churkin, Jr., Paleozoic paleomagnetism and the northward drift of the Alexander Terrane, SE Alaska, J. Geophys. Res., 185, 5281-5296, 1980.

Walker, R. G., and E. Mutti, Turbidite facies and facies associations, in Turbidites and Deep Water Sedimentation, edited by G. V. Middleton and A. H. Bouma, pp. 119-157, Pacific Section, Society of Economic Paleontologists and Mineralogists, Los Angeles, Calif., 1973.

Wells, F. G., and G. W. Walker, Geology of the Galice quadrangle, Oregon, Geol. Quadrangle Map GO-25, scale 1 : 62,500, U.S. Geol. Surv., Reston, Va., 1953.

Wells, F. G., P. E. Hotz, and F. W. Cater, Preliminary description of the geology of the Kerby quadrangle, Oregon, Oreg. Dep. Geol. Miner. Res. Bull., 40, 23 pp., 1949.

Wright, J. E., Tectonic correlations between the south-central Klamath Mountains and Sierra Nevada foothill belt, Geol. Soc. Am. Abstr. Programs, 11, 136, 1979.

Wright, J. E., Paleotectonic setting of the Hayfork terrane, Klamath Mountains, northern California, Geol. Soc. Am. Abstr. Programs, 12, 160,1980 .

Xenophontos, C., and G. C. Bond, Petrology, sedimentation, and paleogeography of the Smartville terrane (Jurassic)-Bearing on the genesis of the Smartville ophiolite, in Mesozoic Paleogeography of the Western United States, Paleogeogr. Symp. 2, edited by D. G. Howell and K. A. McDougall, pp. 291-302, Pacific Section, Society of Economic Paleontologists and Mineralogists, Los Angeles, Calif., 1978.

Young, J. C., Geology of the Willow Creek Quadrangle Humbolt and Trinity Counties, California, Map Sheet 31, Calif. Div, of Mines and Geol., Sacramento, 1978.

(Received May 20, 1981; revised January 6, 1982; accepted January 8, 1982.) 